\section{P. SZABÓ BÉLA}

egyetemi tanár

DE Állam- és Jogtudományi Kar, Jogtörténeti Tanszék

szabo.bela@law.unideb.hu

\section{ÚJVÁRI EMESE}

egyetemi adjunktus

DE Állam- és Jogtudományi Kar, Jogtörténeti Tanszék

ujvari.emese@law.unideb.hu

\title{
A 18. SZÁZADI PESTI JOGI SZAKISKOLA ÉS TANÁRA, PAULUS LUCAS PERGHOLD
}

A 18. század második felében Pest városában egy sajátos oktatási intézmény müködött: a város egy jogi szakiskolát müködtett 15 éven át, ahol elsorban római jogot és kánonjogot oktatott a város alkalmazásában álló professzor. A tanulmány az iskola történetét dolgozza fel külön figyelmet forditva az intézmény egyetlen professzorának, a karintiai származású Paulus Lucas Pergholdnak életére, oktatási tevékenységére és tudományos munkásságára.

Kulcsszavak: jogoktatás, természetjog, disputatiók, felvilágosult abszolutizmus

Law SChool in the $18^{\text {th }}$ Century in Pest and its Teacher, Paulus Lucas Perghold. In the second half of the $18^{\text {th }}$ century, a special educational institution functioned in the city of Pest: the city managed a law vocational school for 15 years, where the professor who was applied by the city mainly taught Roman law and canon law. The study describes the history of the school with special attention to the life, teaching and scientific activity of the only professor of the school, Paulus Lucas Perghold of Carinthian origin.

Keywords: Teaching of law, Natural law, disputationes, enlightened absolutism

A 18. század első felében a jelentősebb magyarországi városok (így Buda és Pest, Pozsony, Sopron) jogéletében két fontos tendencia volt megfigyelhetö. A jogtörténeti irodalom az egyik jellemzőként arra utal, hogy az addig saját statútumaikban, szokásjogi joggyüjteményeikben megfogalmazott jogszabályaikkal és a joggyakorlatot esetlegesen befolyásoló német-osztrák szabályokkal szemben a városok egyre inkább törekedtek a hazai jog (a Tripartitum, Johannes Kithonich perjogi munkája) joggyakorlatukban való alkalmazására. Bónis György megfigyelése szerint - bizonyos ellenállás után - a század közepén a pesti tanács is alkalmazandónak ismerte el az ország törvényeit, és kifejtette,

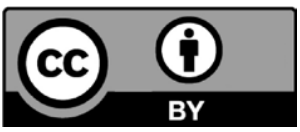

Beérkezett: 2020. 05. 15.

Közlésre elfogadva: 2020. 08. 15.

Copyright GERUNDIUM 
hogy régi jogszabályai elavulása ellenére nem új jogszabályok meghozatalát helyezik elötérbe, hanem a hazai törvényeket kívánják alkalmazni. ${ }^{1}$

Másrészt a 17. század végétől a városok és a központi hatalom közötti viszony jelentős átalakulása következtében a központi hatalom egyre nagyobb hangsúlyt helyezett arra, hogy a városok vezetésébe minél nagyobb számban kerüljenek be olyan - elsősorban katolikus - személyek, akik jogi es közgazdasági ismeretekkel bírnak és ezáltal a szakszerűsödő városvezetések minél „hivatalszerűbben” tudják irányítani közösségeiket, amivel természetesen az uralkodó, a központi hatalom érdekeit is szolgálják. ${ }^{2}$ Ennek megfelelően a központi kormányszékek jelentős mértékben szorgalmazták a jogi műveltség emelését, az egyetemi jogtanulást (még nem a „végzettséget”) a városok lakosai között. Így történt ez Pest vonatkozásában is. A város ügyeinek „Restauratiója” folyamatában, egy 1755-ben kelt tisztújítási eljárást szabályozó királyi rendelet azt írta elő a városnak, hogy a bíró és belső tanácstagok választása során „[...] mind az által alkalmas és értelmes, ez Királyi Városban érdemes, és tanult az mennyiben lehet, Törvénytudó és Catholicus Polgárokra elsöben is Nezés [...] tetetödjék. "”

A tanultság és a jogismeret növelése iránt jelentkező igénynek Pest városa - bizonyos személyes törekvéseket is szolgálva - egy sajátos ötletet megvalósítva kívánt eleget tenni: vezetői egy saját, városi felügyletủ jogi szakiskola felállítása mellett döntöttek az 1750-es évek közepén.

Az alábbiakban ezen iskola történetét vázoljuk fel, és törekszünk mind több adatot feltárni azon személy vonatkozásában is, akinek vállán - szakmai tekintetben - az ötlet megvalósulása nyugodott.

\section{$A z$ iskolaalapitás terve}

A jogi szakiskola ${ }^{4}$ felállításával kapcsolatos első hivatalos dokumentum 1756 októberéből származik, amikor is Pest városának tanácsa folyamodványi előterjesztést tett

${ }^{1}$ Bónis György, „Városigazgatás, várospolitika”, in Budapest története III. A török kiüzésétöl a márciusi forradalomig, szerk. Kosáry Domokos (Budapest: Akadémiai Kiadó, 1975), 183. Budapest Főváros Levéltára, Pest város tanácsának iratai, intimata archivi medii, (továbbiakban: BFL PL Intimata a. m.) 6404/1.

${ }^{2}$ H. NÉMETH István, „Állam és városok. A szakszerűsödés felé vezető első lépések a városi igazgatásban 1670-1733”, Századok 152, 4. sz. (2018): 786., 788-789. és 807. Sopronra: Uő., Az állam szolgái vagy a városképviselői? A központosuló várospolitika hatásai a soproni politikai elit átrendeződésére", Soproni Szemle 61 (2007): 125-141. Pozsonyra: Uő., „Pozsony centrális szerepköreinek hatásai és jellegzetességei a magyarországi városhálózatban”, Történelmi Szemle 60, 2. sz. (2018): 194. Pestre: BóNIs, „Városigazgatás...”, 173.

3 Schmall Lajos, Adalékok Budapest székes föváros történetéhez. I. (Budapest: A Székes Főváros kiadása, 1899), 316.

${ }^{4}$ Az iskola történetével részletesen, levéltári források feldolgozásával foglalkozott MoLNÁR Aladár, „Pest városának jogi tanintézete”, Magyar Szemle (1881): 36-47. GÁrdonYI Albert, „Pest város jogi szakiskolája (1756-1771)", Pestbudai Emléklapok, 3. kötet, 3. füzet, A Historia melléklete (1930.): 101-117. A régebbi irodalomban röviden említette FInÁczy Ernő, A magyarországi közoktatás története 
az udvari kancelláriához, amelyben ahhoz kérte a királynő engedélyét, hogy a város egy iskolát nyithasson a római jog és a kánonjog nyilvános oktatására egy erre a célra a város által alkalmazott tanár vezetésével. A kérelem szerint kísérleti jelleggel négy éves időtartamra kérnék az engedélyt. Kérésüket az alábbiakkal indokolták:

„Több királyi rendelet meghagyja, hogy úgy a városi tanácsba (ad intera senatum), mint egyéb hivatalokra kellően tanult és jogban jártas egyének (litterata et juris perita subjecta) alkalmaztassanak. Ámde a hazai törvényeket és az ország szokásjogát is alig lehet érteni az elmélet nélkül, vagyis a törvények és a természetes méltányosság szellemének ismerete nélkül (absque cognitione rationis legis et naturalis aequitatis)."

A kérelem szerint az alkalmazandó tanár illetményére 400 forint évi fizetést szánnának, ${ }^{6}$ amit a pestis járvány költségeinek a megtérítésére elkülönített összegek kamatjaiból kívánnak előteremteni. Ez az összeg 1758-ban 8500 forintot tett ki, ennek kamatait szánta tehát a város a jogi szakiskola alapítására és fenntartására. ${ }^{7}$

A beadvány szerint a jogtanár kötelessége lenne, hogy a helybeli polgárok gyermekeit és máshonnan jövő diákokat, nemes ifjakat és más királyi városok polgárainak a gyermekeit, akik a filozófiai kurzust már elvégezték (absoluta philosophis) és megfelelő eszközökkel rendelkeznek ahhoz, hogy önmagukat fenntartsák, bevezesse a jogtudományok alapjaiba. ${ }^{8}$

A folyamodvány szerint az iskola elsősorban a pesti polgárok érdekeit szolgálná, hiszen a fiatalok külföldi tanulmányai évente 300 forintot is felemésztenének, és a helyi

Mária Terézia korában. Elsö kötet: 1740-1773. (Budapest: MTA, 1899): 139-141. Újabban: BóNis, „Városigazgatás...”, 183. NAGY Lajos, „Budapest története 1686-1790”, in Budapest története III. A török kiüzésétöl a márciusi forradalomig, szerk. Kosáry Domokos (Budapest: Akadémiai Kiadó, 1975), 196. PeCze Ferenc, „Az első magyarországi jogakadémiák alapítása és a tananyag-korszerűsítés a XVIIIXIX. századfordulóig”, Jogtudományi Közlöny, 3. szám (1968): 146. Uö., „Der Rechtsunterricht in Ungarn im 18. Jahrhundert besonders an den rechtswissenschaftlichen Akademien”, in Die juristische Bildung in der Slowakei und Ungarn bis zum J. 1848, (Bratislava: Slovenské Pedagogické Nakl., 1968), 209-210.

5 Saját fordításában idézi Molnár, „Pest városának...”, 39. Vö. GÁrdonyi, „Pest városi...”, 101.

${ }^{6}$ Megjegyzendő, hogy a nagyszombati jogi karon a római jog és a hazai jog első tanárának illetménye is 400-400 forintra rúgott az 1750-as években. Vö. MolNáR Aladár, A közoktatás története Magyarországon a XVIII. században I, (Budapest: MTA, 1881), 225.

7 GárdonYI, „Pest városi...”, 115. „Pro fundatione videlicet at intertentione studii juris civilis destinatos et constitutos" Budapest Főváros Levéltára, Pest város tanácsának iratai, intimata archivi antiqui, (továbbiakban: BFL PL Intimata a. a.) 4010.

${ }^{8}$ A szegény tanulók kizárását az indokolta a beadvány szerint, hogy a helyi iskolákban már egyébként is sok szegény, kolduló diák tanul (,in Trivialibus, seu humanioribus scholis sufficientes studiosi mendicantes hic darentur"), és ha ezt még egy új intézmény kívülről jövő rászoruló diákjai is megtetéznék, az elviselhetetlen terhet jelentene a város polgársága számára. GÁrDONYI, „Pest városi...”, 101. MolnáR, „Pest városának...”, 39. Elsősorban a piarista gimnázium diákjai között feltételezhetünk szegényebb sorsú diákokat. A város szegény diákok beáramlása elleni törekvéseit néhány példával és adattal illusztrálja GÁRDONYI, „Pest városi...”, 102-103. 
iskola lehetővé tenné ezen költségek megtakarítását. Ugyanakkor a diákok szülői felügyelet alatt maradása megóvhatná őket az elzülléstől, ami hazájuktól távol reális veszély lehet. A vidéki hallgatók lakhatásukért és ellátásukért fizetnének is, és ez a polgárok bevételeit is növelhetné.

Legfőbb „szakmai” érvként azt is előadta tanács a beadványban, hogy az előzetes tervek szerint tanuló ifjak az iskolában szerzett elméleti ismereteiket jól összekapcsolhatnák a Pesten székelő királyi kúria gyakorlatának tanulmányozásával, és így gyakorlati ismereteket szerezhetnének a hazai jogban is. ${ }^{10} \mathrm{Ez}$ egybecsengett az uralkodó törekvéseivel is, aki - mint láttuk - utasításban rendelte el, hogy a városvezetők literátus, a hazai jogot és nyelveket is jól ismerő emberek közül kerüljenek ki. ${ }^{11}$

Az első négy év tapasztalatai alapján kívánják majd - királyi hozzájárulással a végleges működési szabályokat megállapítani, különös tekintettel a hallgatók fegyelmezésére és az általuk a polgárság felé vállalt - koszt és kvártély fejében fizetendő kötelezettségek teljesítésére. ${ }^{12}$

\section{A kiszemelt tanár}

A kancelláriai beadvány elkészítése idején a pesti tanács már kiválasztotta azt a tanárt, akire az intézmény munkájának megtervezését akarta bízni, és akinek kezeire kívánta adni fiai jogi iskoláztatását.

A kiszemelt jogász a karintiai születésű, Gottschee városából származó Paulus Lucas Perghold volt. ${ }^{13}$ Pergholdról - az eddigi irodalomban - azt feltételezték, hogy 1741 körül Bécsben jogot hallgatott, ${ }^{14}$ és ugyanott nyolc évig ügyvédi gyakorlatot is folytatott. Mivel nem volt pénze a doktori fokozat megszerzésére, ezen idő elteltével vissza-

${ }^{9}$ "Nagy haszna lenne az intézetböl mind a város egyes polgárainak, mind a közügynek. Ugyanis igen ritka polgár az, kinek módja van fiát a jog tanulására külországba küldeni s e czélra-mindent összevéve - legalább 300 forintot költeni. A helyben tanittathatással a költség megtakaritás mellett, gyermekeik szülök szemei elött s gondozása alatt növekedvén, sok veszélytöl óvatnának meg. [...] Söt idegenek is jönnének a városba, s a lakosság között nagyobb pénzforgalmat idéznének elö. "Saját fordításában közli MoLNÁR, „Pest városának...”, 39. Ezt a vonatkozást szintén kiemeli NAGY, „Budapest története 1686-1790”, 196.

${ }^{10}$ MolnáR, „Pest városának...”, 39.

11 Bónis, „Városigazgatás...”, 173.

12 Molnár, „Pest városának...”, 39-40.

13 Szinnyei József, Magyar irók élete és munkái, 10., (Budapest: Hornyánszky, 1909), 779-780. Itt életrajzi vázlata Gárdonyi és Molnár szerint szerepel.

${ }^{14}$ Ezt a feltételezést a bécsi egyetem megjelentetett anyakönyvei nem igazolják vissza, mivel azokban a neve nem található meg. Kurt MüHlberger, Hrsg., Die Matrikel der Universität Wien VII. Band: 1715/16-1745/46, Publikationen des Instituts für Österreichische Geschichtsforschung VI. Reihe Quellen zur Geschichte der Universität Wien, 1. Abteilung Die Matrikel der Universität Wien (Wien: Böhlau Verlag, München: Oldenbourg Verlag, 2011). Kurt MüHlberger, hrsg., Die Matrikel der Universität Wien, VIII. Band 1746/47-1777/78, Publikationen des Instituts für Österreichische Geschichtsforschung VI. Reihe Quellen zur Geschichte der Universität Wien, 1. Abteilung Die Matrikel der Universität Wien (Wien-Köln-Weimar: Böhlau Verlag, 2014). 
költözött szülőföldjére. Utóbb járt Padovában is, ahol (állítólag) 1749. szeptember 20-án jogi doktorrá avatták. Ezután ismét Bécsben telepedett le, és előbb magánúton, majd világi tanárként valószínủleg jogot oktatott az 1746-ban alapított Savoyischen Akademie$\mathrm{n},{ }^{15}$ és 1754-ben pályázott a bécsi egyetem Institutio-professzúrájára, ahová azonban a később nagy hírnevet szerzett Martinit ${ }^{16}$ nevezték ki. Pályázatához a „De officio civium rege ejecto" című dolgozatot csatolta, ${ }^{17}$ melyet később Budán adott ki bővebb formában. Talán pályázata sikertelenségéből is fakadtak ellentétei a jogi kar professzoraival, ami végül is a császárváros elhagyására késztette, de ellenérzései nem szűntek meg a jogászprofesszorokkal szemben. ${ }^{18}$

Perghold 1755-ben báró Franciscus Dőry ${ }^{19}$ fiának, Gabrielnek lett a jogtanára és Dőry ajánlásával került kapcsolatba Pest város tanácsával, ahol is Francisvus Skopek (Scopek) főjegyző volt a legfőbb pártfogója. ${ }^{20}$

${ }^{15}$ Fináczy szerint a bécsi savoyai akadémiában lakó fơuri joghallgatókat részesítette magánoktatásban. Fináczy, A magyarországi..., 130. Vö. Johann SchWarz, Geschichte der Savo'schen Ritter-Akademie in Wien vom Jahre 1746 bis 1778 (Wien: Braumüller, 1897). Franz Gruber, Geschichte der k.k. Ing. und der k.k. Genie-Akademie (Wien, 1902). Részben érinti az akadémia jogi oktatását KöKÉNYEsı Zsolt, „A tudomány és a nyilvánosság kapcsolata egy nemesi akadémia példáján. A bécsi Theresianum reprezentációja a 18. században", Világtörténet 1-2. sz. (2012): 40-42.

${ }^{16}$ Martini, Carolus Antonius (1726-1800) innsbrucki tanulmányok után lett 1754-ben - Mária Terézia egyetemi reformjainak sodrában - az Institutiones és a természetjog professzora a bécsi jogi karon. A felvilágosodás egyik legjelentősebb osztrák jogászaként jogalkotói tevékenysége révén nagy hatással volt az osztrák, tanítványai révén a magyar jogi kultúrára is. Michael Hebeis, Karl Anton von Martini (1726-1800). Leben und Werk, Rechtshistorische Reihe 153 (Frankfurt am Main usw.: Peter Lang, 1996). Heinz Barta und Günther Pallaver, Hrsg., Karl Anton von Martini: ein österreichischer Jurist, Rechtslehrer, Justiz- und Bildungsreformer im Dienste des Naturrechts (Wien usw.: Lit, 2007).

${ }^{17}$ A 1761-es kiadás előszavában így ír pályázatáról: „Cum Anno 1754. mense Martio vacantis Antiquissima, ac Celeberima Universitate Viennensi Imperialum Institutionum Professurae causa, non tam mea voluntate, aut illius obtinendae confidentia, quam ex amicorum potius persuasu, \& ut verum dicam, compulsus authoritatis imperio, me apud eos supplex insinuassem, quorum discretissimo aeque, ac justissimo arbitrio supplendae illius cura principali videbatur fuisse authoritate demandata; ut scilicet hiuc muneri congrua experientia, si quae in me esset habilitas, dignoscerentur, praesaga quasi mente fatorum hujus, quod jam vivimus, temporis, gratiose mihi quoque hoc, quod aliis Con-candidatis elaborandum thema datum est, nimirum de Officio Civium Rege ejecto." Pauli Lucae Perghold, U.J.D. De Rege, et Cive, Eorumque Mutuo Officio Opus Christiano-Juridico-Politicum, Observationibus Historicis, criticis, moralibus, \& polemicis illustratum, ac publici Juris factum, Cum sub Faventissimis, ac Gratiotissimis Auspiciis Totius Excelsae Regiae Curiae Judiciariae Selectissimas ex Universo Jure Theses Per triduum publice propugnaret [...] Joannes Szkatsányi, Nobilis Hungarus Lelocziensis ex Comit. Nitriensi, U.J. Auditor emeritus, nec non Inclytae Tabulae Regiae Judiciariae Notarius juratus. Pestini _ Mensis Septembris Anno MDCCLXI, Budae, typis Leopoldi Francisci Landerer Typographi. Praefatio.

${ }_{18}$ FInÁczy, A magyarországi..., 130.

19 Dőry Ferenc (?-1778) 1741-ben nyert bárói, majd 1766 grófi címet és 1777-ben lett királyi fôpohárnok. A Hétszemélyes tábla ülnöke és Zemplén megye főispánja is volt. Fia Gábor 1770-ben királyi kamarás és a szepesi kamara tanácsosa. NAGY Iván, Magyarország családai czimerekkel és nemzékrendi táblákkal 3 (Pest: Ráth Mór, 1853), 374-375.

${ }^{20}$ Magyar Nemzeti Levéltár Országos Levéltár, Kancelláriai levéltár, Originales referadae (a továbbiakban: MNL OL Kanc. Orig. ref.) 1757. nr. 28. 
1756-ban már sajtó alatt lehetett Perghold Institutio-kommentárja, ami elősegíthette magának az iskola ötletének megszületését és alkalmazását is. Lehet, hogy maga Perghold, vagy pártfogói szorgalmazták az egész ügyet. ${ }^{21}$

Tanári tevékenységét nagy elhivatottsággal végezhette, az első években a város is elismerte munkáját és állítólag a hallgatóság is kedvelte, azonban később - mint látjuk majd - többször is összetűzésbe került a városi tanáccsal. ${ }^{22}$

\section{Az intézet tervezett tanmenete}

Perghold már tanárkénti alkalmazása előtt kidolgozta a tervezett iskola tanmenetét, melyről egy német nyelvű emlékiratot készített. Ebben vállalta az előadottak megvalósítását, és valószínűleg az intézmény ezen tervezet szerint kezdte meg utóbb a működését. ${ }^{23}$

A tervezet szerint az előadások minden évben november 15-én kezdődnének és a tanév a következő augusztus végéig tartana. A tanár az ünnepnapok és csütörtökök kivételével előadásait naponta tartaná. Ünnepi időszakként kiesnének a december 23. és január 1., az április 15. és 26., valamint a június 5. és 11. közötti időszakok. ${ }^{24}$

Perghold a teljes tanfolyamot három évesre tervezte. Az első évben a iustinianusi Institutionest adná elő, míg a második és harmadik tanévet a Digesta és kánonjog előadására szánná.

Hogy a felsőbb évesek a Királyi Tábla és Hétszemélyes Tábla üléseit látogathassák („die Sessionen der königlicher und Septemviraltafel zu ferquentieren”) és így a hazai jogban is elmélyülhessenek, számukra úgy tervezte beosztani előadásait, hogy amikor nincs kúriai ülésszak („ausser der Terminszeit”), ${ }^{25}$ akkor az Institutio-előadások naponta fél 9-től 10 óráig tartassanak (egy óra előadás és fél óra ismétlés), míg a Digesta 10 óra és fél 12 között adassék elő. Mikor viszont a kúria ülésezik akkor az előadások sorrendje megfordulna, s előbb a Digesta-előadás, majd az Institutiones következne ugyanezen időrend szerint. Perghold szerint a Digesta fajsúlyossága indokolja, hogy azt két éven át adja elö, illetve a felsőbb évfolyamosok már in praxi is hasznát vehetnék a hallottaknak. A kánonjogot az utolsó két évben hetente három délután (hétfö, szerda, pénteken) 3-tól 4-ig egy-egy órában tervezte előadni. ${ }^{26}$ Ezen tanulmányok révén - mivel a jogtudomány valamennyi ágában elmélyültek - a hallgatók bármely közhivatal ellátására alkalmassá válhatnak. ${ }^{27}$

21 Molnár, „Pest városának...”, 40.

22 Uo.

23 Molnár, „Pest városának...”, 41. A tervezetet a város csatolta az említett kancelláriai beadványhoz.

24 Molnár, „Pest városának...”, 41. GÁrdonyi, „Pest városi...”, 104.

25 Évente 3-4 ülésszakkal számolhatunk a korban, melyek egyenként 4-6 hétig tartottak. MolNÁR, „Pest városának...”, 41.

26 Molnár, „Pest városának...”, 42. GÁrdonyi, „Pest városi...”, 103.

27 Gárdonyi, „Pest városi...”, 104. 
Perghold az Institutionest saját tankönyvéből kívánta előadni, ami a tervezet elkészültekor már nyomdakész volt. A Digesták kommentárjaként - saját kommentárjának elkészültéig - Henricus Zoesius munkáját tervezte tanítani. ${ }^{28} \mathrm{~A}$ kánonjog oktatásában pedig Andrea Vallensis munkáját ${ }^{29}$ kívánta felhasználni. ${ }^{30}$

A tervezet szerint minden hallgató tanulmányai kezdetén négy körmöci aranyat lenne köteles befizetni, de ez alól a pesti származású hallgatók és a nemesek, illetve azok, akiknek atyja a Kúrián áll alkalmazásban mentesülnének. Utóbbiak tetszésére lenne bízva, hogy fizetnek-e és mennyit tanulmányaikért. ${ }^{31}$

\section{A képzés engedélyezése}

A pesti városi tanács beadványát a kancellária - a királynő utasítására - 1756. november 9-én megküldte a Helytartótanácsnak véleményezés céljából. A vélemény megfogalmazására egy helytartótanácsi és kamarai vegyesbizottságot küldtek ki, amely gróf Johannes Csáky elnökletével összeülve 1757. január 15-i ülésén pozitívan állt a kérelemhez, és pártolta az engedély megadását. Az indokolás jogtörténetileg legérdekesebb részében kifejti a bizottság, hogy az iskola engedélyezése annál is indokoltabb, mivel hazai törvényeink legnagyobb részben a római jogon alapulnak (,[...] ut studium Praesertim Juris Civilis, in quo leges quoque nostras municipales potissime fundari indubium est [...]").32

Ugyanakkor a bizottság kikötötte, hogy a szerződtetendő tanár tegyen előzetes vizsgát szakmai alkalmasságának megítélése céljából. Azt is megfogalmazták, hogy a pestieken kívül mindenki által fizetendő beiratkozási díjat három aranyra mérsékeljék, mivel akkoriban a bécsi egyetemen is ez a díj volt szokásban. ${ }^{33}$

${ }^{28}$ Zoesius, Henricus (1571-1627) a leuveni egyetem római jogász professzora volt, akinek előadásait lejegyezték és kommentárként adták ki halála után. Kommentár maradt fenn neve alatt a hủbérjoghoz, a iustinianusi gyűjteményekhez (Institutuiones, Digesta, Codex) és IX. Gergely dekretális gyüjteményéhez. Népszerủ katolikus jogászként tartották számon a 17-18. században, akinek Digesta (Pandekta)és dekretális-kommentárjait az osztrák egyetemeken sokáig hivatalos tankönyként használták. Vö. [Johann Friedrich] von Schulte, „Zoesius, Heinrich”, in Allgemeine Deutsche Biographie 45 (Leipzig: Duncker \& Homblot, 1900), 402. P. J. Blok és P. C. Molhuysen, Nieuw Nederlandsch biografisch woordenboek Deel 3 (Leiden: Sijthoff, 1914), 1519-1520. A kérdéses kommentár: Commentarius ad Digestorum seu Pandectarum juris civilis libros L, (Leuven, 1645), amelynek valamely későbbi kiadását használhatta Perghold.

${ }^{29}$ Vallensis, Andreas [Delvaux, André] (1569-1636) kánonjogász professzor volt szintén a leuveni egyetemen, Zoesius kortársa és kollégája. IX. Gergely rendeletgyüjteményére épülő tankönyvét maga rendezte sajtó alá. Paratitla sive summaria et methodica explicatio Decretalium d. Gregorii P. IX., Leuven, 1628 és 1632), amelynek számos későbbi kiadása ismert. Még 1772-ben is kiadták a jezsuiták Nagyszombatban. Vö. [Johann Friedrich] von Schulte, „Vallensis, Andreas”, in Allgemeine Deutsche Biographie 39 (Leipzig: Duncker \& Homblot, 1895), 470.

${ }^{30}$ Molnár, „Pest városának...”, 42. GÁrdonyI, „Pest városi...”, 104.

31 Molnár, „Pest városának...”, 42. GÁrdonYI, „Pest városi...”, 104. Az emlékirat: Budapest Főváros Levéltára, Kancelláriai iratok, 1756. november 38. sz.

32 Idézi Molnár, „Pest városának...”, 42.

${ }^{33}$ Gárdonyi, „Pest városi...”, 104. Budapest Főváros Levéltára, Helytartótanácsi iratok, 1757. évi 36. sz. Molnár, „Pest városának...”, 42. 
A kancellária a tervezetet nemcsak a Helytartótanácsnak, hanem a Királyi Kúriának is megküldte véleményezésre. A Kúria 1757 februárjában úgy foglalt állást, hogy az iskola már csak azért is hasznos lenne, mert olyan hallgatóknak is tanulási lehetőséget kínálna, akik vagyoni okokból nem gondolhatnának jogi tanulmányokra. A Kúria azonban nem támogatta azt a tervet, hogy a tanár saját tankönyve alapján oktasson, hanem a más jogoktatási intézményekben használatos könyvek alkalmazását pártolta. ${ }^{34}$

A kancellária a vélemények figyelembe vételével terjesztette az uralkodó elé a kérelmet. A királynő végül hozzájárult az előterjesztéshez, és így a kancellária 1757. március 1-jén a jogi szakiskola működésének engedélyezéséről értesítette a Helytartótanácsot. Az engedély egyelőre négy évre szólt, és azt a kikötést is tartalmazta, hogy az alkalmazandó tanár csak a bécsi egyetem jóváhagyásának megszerzése után taníthat saját tankönyvéből, és addig az egyetemeken használatos tankönyvek alapján oktasson. Az engedély azt is elöírta, hogy mivel Pest városa magának kívánja fenntartani az iskola közvetlen felügyeletét, évente köteles legyen jelentést tenni az iskola működéséről a Helytartótanácsnak, amely azt a királynőnek legyen köteles továbbítani. ${ }^{35}$

Bár az engedély megadásáról a Helytartótanács csak 1757. március 7-én értesítette a várost, ${ }^{36}$ tudjuk, hogy Perghold 15 hallgatóval már 1756. november 15-én megkezdte oktató munkáját. ${ }^{37} \mathrm{Ez}$ a tény maga nem okozott problémát, mivel utólag az engedély megérkezett, de az, hogy Perghold saját tankönyvét használta, nem került jóváhagyásra. Perghold az ebből fakadó későbbi gondokat elkerülendő előterjesztésben adta elő a város vezetése felé, hogy saját könyvének használatát az indokolta, hogy az előadások megkezdésééig nem tudta hallgatóit más könyvekkel ellátni. ${ }^{38}$

A város tanácsához intézett ezen beadványában azt is előadta, hogy továbbra is szeretné, ha megengednék neki, hogy saját tankönyvét használja, mivel ez könnyebbé teszi a dolgát, és a tanár tekintélyét is növeli, ha saját könyvét magyarázhatja. A Bécsben használt tankönyvek egyébként is vázlatosak, nem kínálnak elegendő ismeretet a hallgatóknak, s szerzőik egyébként sem katolikusok. Éppen ezért ezen szerzők műveit azért is kerülni kellene Magyarországon, nehogy a nem-katolikusok elbízzák magukat, s azt hirdethessék, hogy nem léteznek megfelelő katolikus jogi szerzők. Egyébként sem szabad

${ }^{34}$ GÁrdonyI, „Pest városi...”, 106. MNL OL Kanc. Orig. ref. 1757. nr. 28.

35 Gárdonyi, „Pest városi...”, 106. MNL OL Kanc. Orig. ref. 1757. nr. 20. Vö. Molnár, „Pest városának...”, 42.

${ }^{36}$ Magyar Nemzeti Levéltár Országos Levéltár, Helytartótanácsi levéltár, Acta miscellanea (továbbiakban: MOL OL Helytartót. Acta misc.) fasc. 74. nr. 452.

37 Perghold 1758. májusi jelentése szerint az első hallgatók között hat pesti polgárfi volt, további három nemes jött Pestről, Pest, Nyitra, Csongrád valamint Ugocsa megyéből, Kassáról és Szegedről egy-egy nemes, míg Nagyszombatból egy polgári státuszú hallgató érkezett. MNL OL Kanc. Orig. ref. 1757. nr. 28. Vö. MolnáR, „Pest városának...”, 43.

${ }^{38}$ GÁrdonyI, „Pest városi...”, 106. Forrás: „[...] quod traditionem meam concernit, Am. magistratui notum per se est, me eam bona fide, et spe clementissimae aulicae approbationis 15. novemb. elapsi Anni 1756. ut pote in tempora ita, repente innoasse, ut auditores meos de in aliis universitatibus tradi solitis commentariis praesidere moraliter fuerit impossibile [...]”. Idézi Molnár, „Pest városának...”, 46. 
megadni a hallgatóknak a lehetőséget, hogy már fiatalon megkedveljék a protestáns szerzők műveit. A hallgatók számára fontos, hogy jól megtanulhassanak egy könyvet. Saját Institutio-magyarázatának megfelelőségét az is igazolja szerinte, hogy a budai föcenzor átvizsgálta azt, és nem talált benne kivetnivalót, s egyébként is a Kúria és a városi tanács előtt már több nyilvános vitatkozás lezajlott ezen munka alapján. ${ }^{39}$ De kijelenti azt is, hogy természetesen a legfelső parancsnak - ha ez szükséges - engedelmeskedni fog, ugyanakkor kérte a tanácsot, hogy járjanak közben saját tankönyve használatának engedélyezése érdekében. ${ }^{40}$ Megjegyzendő, hogy más tankönyvének bevezetése egyértelműen anyagi veszteségekkel járt volna Perghold számára. A tanács nem vitte tovább a kérelmet, azonban hallgatólagosan helyben hagyta a professzor gyakorlatát.

\section{A megualósult tanrend}

Az intézmény müködési engedélyének elnyerése után Perghold nyomtatott hirdetményben tette közzé az iskola tanulmányi rendjét. ${ }^{41}$ Ezen dokumentum szerint az adott tanév november 7-én kezdődött és következő év szeptember 7-ig tartott. A hároméves tanfolyam az eredeti emlékirat szerinti megosztását mutatta az oktatott anyagnak. A gyakorlati ismeretek megszerzését szolgáló törvényszéki látogatások is benne maradtak a tantervben. ${ }^{42}$

A hirdetmény szerint a professzor havonta magán-disputatiók megtartását vállalta, míg évente háromszor nyilvános vitatkozásokat tervezett. Ez utóbbiakat mindig a Királyi Kúria ülésszakának idejére tervezte, hogy a hallgatók előmeneteléről az ország nagyjai is meggyőződhessenek. ${ }^{43}$

Ezen hirdetmény szerint hallgatónak jelentkezhettek a nemesek, a pesti polgárok fiai és azon gazdagabb külső polgárok fiai, akik lefizetik a négy körmöci aranyat. Elö-

39 1757. március 13-án rendezték meg a hivatkozott nyilvános vitatkozást.

${ }^{40}$ Perghold beadványát ismerteti MolNár, „Pest városának...”, 43. BFL PL Intimata a. a. 3608. Vö. GÁrdonyI, „Pest városi...”, 106.

${ }^{41}$ A hirdetményt facsimilében közli Gárdonyi, 105 GÁrdonYI, „Pest városi...”, BFL PL Intimata a. a. 4298.

42 "Cursus totius studii triennio circumscriptus est ita, ut Juris tyrones primo anno absolvant Institutiones, secundo \& tertio Digesta, \& Jus Canonicum. Institutiones explanabuntur singulis diebus mane ab hora 8. ad 9. Digesta ab hac ad 10. Post meridiem ter septimana a. 3. ad 4. explanabitur Jus Canonicum. Secundi, \& tertii anni auditores (primi enim anni auditoribus, quod Juris nullam adhunc habeat cognitionem, summe disvadetur) \& in Patvariis se exercere, \& Sessiones frequentare, sicque eodem temporis decursu \& et in theoria, \& in praxi se perficere, ac Reipublice, ad ejusque publica munia, idoneos se se cives reddere nulla majori poterunt difficultate."

43 "Praeter quotidiana exercitia mensibus singulis privatae habebuntur disputationes, publicae, solennesque in anno ter, semper tamen solum tempore, quo aut Inclyta Tabula Regia Judiciaria, aut tota Excelsa Curia fuerit congregata, idque ut Nobilis Studiosa Juventus coram his Patriae Patribus, \& Inclytae Regni Proceribus in firmam futurae accomodationis spem solertia sua relati inde fructus possit specimina exhibere." BFL PL Intimata a. a. 4298. 
feltételül elvárt volt, hogy a jelentkező lezárt filozófiai tanulmányokkal rendelkezzen, vagy legalább a logikát már maga mögött tudja. Azok, akik csak a retorikát vagy a poétikát végezték el, nem voltak felvehetők. ${ }^{44}$

Perghold a hirdetmény szerint azt is vállalta, hogy évi 200 forintért ebédet és vacsorát, valamint kétágyas szobákban elhelyezést biztosít nyolc hallgatónak. Az árban a tandíjmentesség, a világítás, a kézikönyv biztosítása és korrepetitori segítségnyújtást is beleértendő volt. Azonban ágynemüt és evőeszközöket a hallgatóknak kellett hozniuk. A nyolc hallgatón kívül másoknak is ígérte, hogy segít lakhatásuk megoldásában. ${ }^{45}$

1758 őszétől kezdődően Perghold naponta 3-4 órát tartott a három évfolyamon. Valószínűleg a másod- és harmadévesek ugyanazt az előadást hallgathatták. Ebből következik, hogy Perghold ezen évfolyamokon nem kezdte minden tanévben újra az anyagot, hanem évről-évre folyamatosan előre haladva kommentálta a Digesta és a kánonjog anyagát. Az Institutio-kurzust sem valószínű, hogy minden évben újra kezdte volna. A kor egyetemein is több (legalább két) évig tartott egy-egy Institutio-előadássorozat.

Az előadások mellett - mint láttuk - vállalt kötelezettsége volt a professzornak havonta legalább egy gyakorló vitatkozás előadási órákon kívüli lebonyolítása, és évente három alkalommal nyilvános disputatiók megszervezése, illetve azokra a hallgatók felkészítése. Mint alább látni fogjuk, a nyilvános vitatkozások alapjául olyan egy-egy mondatos jogi állítások szolgáltak, melyek a különböző jogterületekről származhattak. Általában a magán-, illetve gyakorló vitatkozások is ilyen rövid tanmondatok feletti csatározást hoztak: a respondens feladata a valószínűleg a professzor által kidolgozott és összeállított tételek megvédése volt, általában két opponens ellenérveivel szemben. ${ }^{46}$ Ilyen magán- vagy gyakorló disputatiók a pesti jogi szakiskola hallgatóitól nem maradtak az utókorra, valószínűleg nem is kerültek kinyomtatásra.

Perghold 1758. májusi jelentése szerint már az első tanévben négy hallgató disputált így, míg a másodikban szintén négy vitatkozót sorolt fel. Ekkor írja, hogy nyilvános disputatiót még nem rendeztek, mivel a szellemi tehetség és a költségek kifizetésének tehetsége eddig nem találkozott ugyanabban a hallgatóban. ${ }^{47} \mathrm{Az}$ 1758/59-es tanévről beszámolva azonban már két magánvitatkozás és két Kúria előtt megrendezett disputatio

44 "Ad studium hoc admittuntur sine discrimine omnes Nobiles, honestiorumque Civium liberi, qui propriis se se intertenere sumptibus, mihique pro Collegio unius anni initio ingressus sui ad minimum 4. Cremnicensis Aureos queunt deponere, modo tamen jam fuerint Philosphi, aut saltem maturi, \& bene fundati Logici absoluti, quales allatis se mihi a professoribus, aut si a studiis jam diutius absunt, ab Inclyto Comitatu, aut ipso, ex qua venient Amplissimo Civitatis Magistratu authenticis testimoniis debebunt comprobare. Rhetore aut Poëtae spem sibi accessus nullam faciant."BFL PL Intimata a. a. 4298.

45 GárdonYI, „Pest városi...”, 104. BFL PL Intimata a. a.4298.

46 Molnár, „Pest városának...”, 43.

47 GÁRDOnYI, „Pest városi...”, 108. „[...] habitae sunt hae privatae disputationes et hoc, et praeterito anno semper die Justiniano ne vel hora ordinariis destinata collegiis intermitteretur. [...] Publicam hoc anno nullam adhuc habui, at non mea culpa, sed quia qui sufferendos sumptus haberet, capacitatem desiderat, qui hanc haberet, sumptus requirit aut sumptibus parcit [...]. "Idézi MolnÁR, „Pest városának...”, 47. 
téziseit csatolta jelentéséhez. ${ }^{48}$ Azt, hogy a későbbiekben legalább megközelítőleg tartották-e az iskolában a vállalt vitatkozás-sűrűséget, források hiányában nem tudhatjuk.

Azonban szemben a magánvitatkozásokkal, a Perghold által elnökölt nyilvános vitatkozásoknak maradtak fenn nyomai. Az önálló nyomtatványként vagy Perghold egy munkája - külön címlappal, illetve anélkül elkülönített - elö-, vagy utócsatolmányaként, esetleg mindkét módon fennmaradt nyomtatványok címlapjai és ajánlásai igazolják, hogy az előre kinyomtatott tételek feletti ünnepélyes szócsata egy része valóban a Királyi Kúria nyilvánossága előtt folyt le. A címlapok szerint egyik-másik vita három napot (per triduum) is igénybe vehetett. Az is bizonyos, hogy ezeknek az ünnepélyes vitatkozásoknak jelentősebb anyagi vonzatai is voltak, így csak a tehetősebb hallgatók engedhették meg ezt maguknak.

A néhány, szövegében is megismerhető disputatio közös jellemzője volt, hogy témaválasztásukban - eltérően például a németországi egyetemeken általános gyakorlattól ${ }^{49}$ nem monografikus jellegűek - vagyis egy jogi kérdéskört több-kevesebb alapossággal elemző szövegek - voltak, hanem több jogterületről összeválogatott, egy-egy mondatba foglalt jogszabályi tételt felvonultató állítás-folyamok. A tézisek száma 60 és 160 között váltakozott. A vegyes jellegü állításokban nem csak a Perghold által oktatott római és kánonjogi elvek jelentek meg, hanem a természetjog, a nemzetközi jog és a büntetőjog elvei is vita-anyagot szolgáltattak. Sőt több esetben a hazai jogból is találhatók állítások a tézisek között. A hallgatók gyakran ajánlották munkáikat - több oldalas alázatos előszavak formájában - addigi vagy remélt támogatóiknak, általában magas pozíciót betöltő egyházi-, illetve világi méltóságnak.

Ma mindösszesen kilenc olyan nyomtatott jogi disputatiót ismerünk, amelyet Perghold elnökletével a jogi szakiskolát látogató vagy látogatott fiatalember védett meg. ${ }^{50}$

${ }^{48}$ Molnár, „Pest városának...”, 47.

49 A korabeli jogi disputatiók tárgyalási mód szerinti különbségeire vö. SzABó Béla, „Előtanulmány a magyarországi joghallgatók külföldi egyetemeken a XVI-XVIII. században készített disputatióinak (dissertatióinak) elemzéséhez", Publicationes Universitatis Miskolciensis, Sectio Juridica et Politica, Tom. VIII. Fasc. 5. (1993): 96-98.

${ }^{50}$ A Perghold műveivel fennálló esetleges nyomdatechnikai kapcsolatra a professzor műveinek ismertetése során történik utalás. 
A Perghold elnöklete alatt megvédett ismert vitatkozások

\begin{tabular}{|c|c|c|c|c|c|c|}
\hline 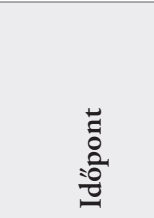 & $\Xi$ & 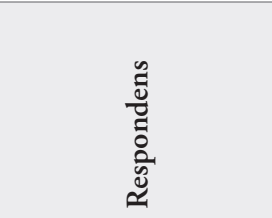 & 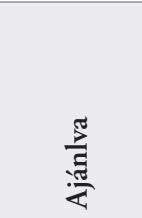 & 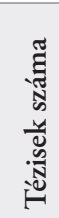 & 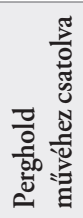 & 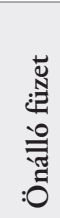 \\
\hline $\begin{array}{l}1761 . \\
\text { szeptember }\end{array}$ & $\begin{array}{l}\text { Theses ex Jure } \\
\text { Universo, hoc est } \\
\text { ex Jure Divino, } \\
\text { Naturae, Gentium, } \\
\text { Hungarico, Civili, } \\
\text { Canonico, Criminali, } \\
\text { Feudali, nec non } \\
\text { Publico Generali } \\
\text { Selectae }\end{array}$ & $\begin{array}{l}\text { Joann. Szkatsányi, } \\
\text { Nobilis Hungarus } \\
\text { Lelocziensis ex } \\
\text { Comit. Nitriensi, } \\
\text { U. J. Auditor } \\
\text { emeritus, nec non } \\
\text { Inclytae Tabulae } \\
\text { Regiae Judiciariae } \\
\text { Notarius juratus }\end{array}$ & $\begin{array}{l}\text { Excelsa } \\
\text { Regia } \\
\text { Curia } \\
\text { Judiciaria }\end{array}$ & & igen & igen \\
\hline $\begin{array}{l}1763 . \\
\text { szeptember }\end{array}$ & $\begin{array}{l}\text { Theses ex Jure } \\
\text { Universo, hoc est } \\
\text { ex Jure Divino, } \\
\text { Naturae, Gentium, } \\
\text { Hungarico, } \\
\text { Civili, Canonico, } \\
\text { Criminali, Feudali } \\
\text { nec non Publico } \\
\text { Generali Selectae }\end{array}$ & $\begin{array}{l}\text { Georgius Jankovics. } \\
\text { U. J. Auditor } \\
\text { Emeritus, Ac } \\
\text { Inclytae Tabulae } \\
\text { Regiae Judiciariae } \\
\text { Notarius Juratus }\end{array}$ & $\begin{array}{l}\text { Franciscus } \\
\text { Barkoczi } \\
\text { de Szala }\end{array}$ & 61 & igen & igen \\
\hline $\begin{array}{l}1763 . \\
\text { március }\end{array}$ & $\begin{array}{l}\text { Selectas ex I. } \\
\text { Imperialium } \\
\text { institutionum libro } \\
\text { theses Hungarico- } \\
\text { canonico-civiles et } \\
\text { pro parte feudales }\end{array}$ & Nicolaus Piukovics & $\begin{array}{l}\text { Franciscus } \\
\text { Barkoczi } \\
\text { de Szala }\end{array}$ & & igen & \\
\hline 1763. & $\begin{array}{l}\text { Theses ex Universo } \\
\text { Jure hoc est [...] } \\
\text { ex jure divino [...] } \\
\text { feudali necnon } \\
\text { publico generali } \\
\text { selectissimus }\end{array}$ & $\begin{array}{l}\text { Joannes } \\
\text { Evangelista Aegydius } \\
\text { Jenövein, } \\
\text { Hungarus Aradiensis }\end{array}$ & $\begin{array}{l}\text { Georgius } \\
\text { Fekete }\end{array}$ & & & igen \\
\hline $\begin{array}{l}1766 . \\
\text { szeptember }\end{array}$ & $\begin{array}{l}\text { Theses ex Jure Divino } \\
\text { Naturae, Gentium, } \\
\text { Hungarico- } \\
\text { Canonico-Civili, } \\
\text { Feudali, Criminali, } \\
\text { et Pro Parte Publico } \\
\text { Generali Selectas }\end{array}$ & $\begin{array}{l}\text { Martinus Mihálkó } \\
\text { Civis Hungarus } \\
\text { Budensis, ac } \\
\text { Jurium in Primum } \\
\text { Annum Auditor }\end{array}$ & $\begin{array}{l}\text { Josephus } \\
\text { Batthyany }\end{array}$ & 139 & igen & \\
\hline
\end{tabular}




\begin{tabular}{|c|c|c|c|c|c|c|}
\hline 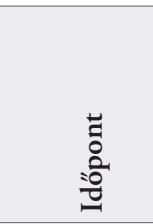 & ชี & 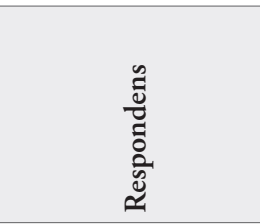 & $\frac{\pi}{\frac{\pi}{\sqrt{2}}}$ & 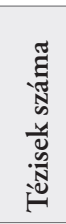 & 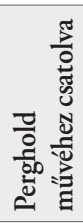 & 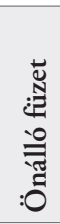 \\
\hline 1766. & $\begin{array}{l}\text { Theses ex Jure } \\
\text { Universo, hoc est } \\
\text { ex Jure Divino, } \\
\text { Naturae, Gentium, } \\
\text { Hungarico, Civili, } \\
\text { Canonico, Criminali, } \\
\text { Feudali, } \\
\text { nec non Publico } \\
\text { generali Selectas }\end{array}$ & $\begin{array}{l}\text { Martinus Csombo } \\
\text { [...] U. J. Auditor } \\
\text { emeritus }\end{array}$ & $\begin{array}{l}\text { Maria } \\
\text { Christina } \\
\text { et } \\
\text { Albertus } \\
\text { Augusti }\end{array}$ & & igen & igen \\
\hline $\begin{array}{l}1768 . \\
\text { február }\end{array}$ & $\begin{array}{l}\text { Theses CL. ex I. } \\
\text { Institutionum } \\
\text { libro selectas }\end{array}$ & $\begin{array}{l}\text { Martinus Járdoss, } \\
\text { Nob. Hung. } \\
\text { Osgyanensis } \\
\text { ex Comitatu } \\
\text { Kis Hontensi } \\
\text { U. J. in primum } \\
\text { Annum Auditor }\end{array}$ & $\begin{array}{l}\text { Johannes } \\
\text { Illésházy }\end{array}$ & 150 & igen & igen \\
\hline $\begin{array}{l}1768 . \\
\text { szeptember } \\
26 .\end{array}$ & $\begin{array}{l}\text { Theses ex } \\
\text { IV. imperialium } \\
\text { institutionum libris } \\
\text { selectas Hungarico- } \\
\text { canonico-civiles et } \\
\text { pro Parte Feudales }\end{array}$ & $\begin{array}{l}\text { Petrus de Vaskó } \\
\text { Nobilis Hungarus } \\
\text { Vedrodiensis } \\
\text { ex Comitatu } \\
\text { Posoniensi U. J. } \\
\text { in primum } \\
\text { Annum Auditor }\end{array}$ & $\begin{array}{l}\text { Antonius } \\
\text { Károlyi }\end{array}$ & 162 & igen & \\
\hline $\begin{array}{l}1771 . \\
\text { szeptember }\end{array}$ & $\begin{array}{l}\text { Theses ex } \\
\text { Jure Divino, } \\
\text { Naturae, Gentium, } \\
\text { Hungarico, Canonico, } \\
\text { Civili, Feudali, } \\
\text { Criminali et pro parte } \\
\text { Publico-generali }\end{array}$ & $\begin{array}{l}\text { Thomas nob. } \\
\text { de Orlandini } \\
\text { Hungarus Agriensis } \\
\text { ex com. Heves }\end{array}$ & & & igen & igen \\
\hline
\end{tabular}




\section{Az jogi iskola látogatottsága}

Arról, hogy az intézmény tizenötéves fennállása alatt hányan hallgatták Perghold elöadásait, csak töredékes adatok állnak az utókor rendelkezésére.

1758-ban - mint láttuk - 16 új elsóéves lépett be a képzésbe, melyek között hat volt pesti polgár fia és három pesti nemesé. Az első év tanulóiból öt fö maradt a második tanévre, illetve volt egy kánonjogot hallgató is. ${ }^{51} \mathrm{~A}$ második évben 15 új hallgató jelentkezett, akik között hat nemes és nyolc pesti polgárfi volt. ${ }^{52}$

1764-ben - amikor talán már négy éves volt a tanfolyam - összesen 44 hallgatója volt az iskolának, 24 első-, 11 másod-, 5 harmad- és 4 negyedéves. ${ }^{53} \mathrm{Az}$ elsőévesek az ország minden részéből, de főleg Zala megyéből érkeztek, s volt közöttük debreceni polgár is. Érdekes, hogy az ekkor lajstromozott hallgatók mindegyike nevelőként dolgozva biztosította megélhetését, ami jelentős konfliktusokhoz vezetett Perghold és a piarista iskola vezetése (és a városvezetés) között. ${ }^{54}$

\section{Müködési nehézségek}

Az iskola működése a rendelkezésre álló töredékes adatok szerint nem volt zavaroktól és vitáktól mentes.

Perghold már az első tanév befejezése után fizetésemelésért folyamodott a pesti tanácshoz, panaszolva, hogy 400 forintnyi fizetése az általa bérelt ház bérleti díjára is alig elég, és még a tanterem bérlése is őt terheli. (Nem tudjuk pontosan hogy mikortól, de Perghold - egy 1768-as iratból kitűnően - a jezsuiták pesti házában lakhatott és ugyanitt folyhatott az oktatás is. ${ }^{55}$ ) Kérte tehát már az első időkben, hogy a város vállalja magára lakbérének kifizetését. A tanács ezt a kérést méltányosnak találta és tovább tolta a kérést az udvari kamarához kérve, hogy engedélyezze a pestisköltségekre kapott összeg megmaradt kamatjainak kiutalását Perghold lakhatási költségeire. A kamara a kérést megtagadta. ${ }^{56}$ Erre Perghold a nádorhoz és a Helytartótanácshoz fordult panaszkodva nehéz megélhetésére, felhozva, hogy egy iparos is jobban él, mint ő, a jogászprofesszor.

${ }^{51}$ Molnár, „Pest városának...”, 43.

52 Perghold 1758-as jelentésében az első két évfolyam névsora fennmaradt. Közli GÁrdonYI, „Pest városi...", 108.

53 Molnár, „Pest városának...”, 43. és GárdonYI, „Pest városi...”, 111., is 43 hallgatóról ír, de a Gárdonyi által közölt jegyzék 44 nevet tartalmaz.

54 GÁrdonyI, „Pest városi...”, 111. Összefoglalja a konfliktus lényegét is: a magántanítóskodást vállaló, de erkölcsi szempontból kifogásolható magatartású joghallgatókat a piarista atyák távol akarták tartani tanítványaiktól. Perghold kompromisszumokra is kész volt a joghallgatók megélhetésének biztosítása érdekében.

55 Gárdonyi, „Pest városi...”, 115. Az épület a mai V. kerületben, a Kossuth és Semmelweis utcák sarkán állhatott.

56 GÁrdonyI, „Pest városi...”, 107. BFL PL Intimata a. a. 3608. MolnÁr, „Pest városának...”, 44. 
Előadta, hogy családjával fütetlen lakásban alszik, míg a tanterem fütéséről gondoskodnia kell és annak a takarítását is maga végzi. ${ }^{57}$

A kérvényt a város is támogatta, az ügy egy vegyes bizottság vizsgálata után ${ }^{58}$ megjárta a Helytartótanács mellett a kancelláriát is, és végül úgy zárult, hogy megengedték az említett kamatok (104 forint) Pergholdnak való kiutalását, így fizetése ennyivel megnövekedett. ${ }^{59}$

Ebben a huzavonában kapott lehetőséget Perghold, hogy számot adjon a hallgatóitól az első két évben beszedett beiratkozási díjakról: az első két évben az önkéntes befizetések révén összesen 14 arany bevétele volt három hallgatótól. A pesti polgárok mentesítve voltak, több nemes hallgató szegénységére hivatkozva nemcsak három aranyat nem fizette ki, de Perghold volt kénytelen számukra tankönyveket adni, sőt néhányuknak a disputatiós költségeit is a professzor állta. ${ }^{60}$

A jogi szakiskola mindennapi működéséről sokatmondó képet azon vizsgálat eredményeiből nyerhetünk, amelyet - tízéves működés után - 1767 közepén a királyi biztosként fellépő Paulus Szlávy királyi jogügyigazgató a pesti közállapotok felderítése okán folytatott le. ${ }^{61}$ Jelentésben Szlávy ${ }^{62}$ arról számolt be, hogy a jogi iskola felállítását 1756-ban elsősorban Scopek föjegyzo ${ }^{63}$ szorgalmazta, akinek fia éppen akkor végezte el a bölcsészeti kurzust és jogot kívánt tanulni. ${ }^{64} \mathrm{~A}$ pesti tanács nagyobb része már akkoriban is ellenezte a tervet, és az iskola tevékenységével szembeni ellenérzések a későbbiekben csak még inkább elhatalmasodtak. Különösen akkor, mikor Scopek ígéretére hivatkozva Perghold 800 forint fizetést igényelt. ${ }^{65}$ Szlávy ugyanakkor hangsúlyozta, hogy az 504 forintos fizetés nem elegendő a jogtanár megélhetésére és utalt Perghold adósságaira is. Azonban kijelentette, hogy a fizetésemelés nem az ő hatáskörébe esik.

Külön foglalkozott Szlávy a hallgatók magatartásával is, melyet a tanács hangsúlyosan szóvá tett: állandó éjjeli kicsapongások zavarják a várost, aminek okául a vezetés azt jelölte meg, hogy válogatás nélkül történik a hallgatók felvétele és - szemben például az egri Foglareanummal - a pesti jogi iskolának nincs tanulmányi és fegyelmi szabályzata.

57 „[...] ordinarii alicuius opificis more magis, quam juris professoris cogar vitam ducere.” MOL OL Helytartót. Acta misc. fasc. 74. nr. 452. és BFL PL Intimata a. a. 3608.

${ }^{58}$ A bizottság azt javasolta, hogy kérjenek a várostól pontos kimutatást a hallgatók létszámáról és arról, hogy milyen egyéb jövedelmei vannak a jogtanárnak.

59 GÁrdonyI, „Pest városi...”, 107. BFL PL Intimata a. a. 3608. Molnár, „Pest városának...”, 44.

${ }^{60}$ Molnár, „Pest városának...”, 44. GÁrdonYI, „Pest városi...”, 108-109.

${ }^{61}$ Vö. BóNIs, „Városigazgatás...”, 174.

${ }^{62}$ Szlávy igazságszolgáltatási pályafutására vö. újabban. SЕвőк Richárd, „Professzionalizáció az igazságszolgáltatásban a 18. században”, Századok 150, 4. sz. (2016): 955-956.

${ }^{63}$ Scopek 1727 utáni ügyészi, főjegyzői és tanácsnoki tevékenységére és befolyására vö. BóNIs, „Városigazgatás...”, 171-176.

${ }^{64}$ Szlávyra utalva ezt feltételezi Bónis is. Vö. BóNıs, „Városigazgatás...”, 183. Scopek fiai taníttatása érdekében pártolta már 1746-ban a piaristák filozófiai kurzusának beindítását is. Vö. TAKÁcs Andor, A föváros alapitotta piarista kollégium története (Budapest: Hornyánszky, 1895), 184.

${ }^{65}$ 1777-ben Perghold azt állította, hogy eredetileg 800 forint évi fizetést, szabad lakást és 12 öl tűzifát ígértek neki. GÁrdonYI, „Pest városi...”, 115. 
Szlávy a felvétellel kapcsolatosban arra az álláspontra helyezkedett, hogy a mágnások és előkelő nemesek gyermekei kivételével a felvételről a városbíró döntsön. Javasolta a tanácsnak, hogy a tanulmányi és fegyelmi rend felügyeletével a tanács egy vagy két tanácsost bízzon meg. ${ }^{66}$

Szlávy rendelkezéseit a tanács 1767 novemberében Perghold tudomására hozta, de ő továbbra is egy személyben döntött a hallgatók felvételéről. Végül a tanács az iskola bezárásával fenyegette meg Pergholdot arra az esetre, ha továbbra is ellenszegül a rendelkezéseknek és továbbra is válogatás nélkül vesz fel hallgatókat.

Annak is maradt nyoma, hogy Perghold folyamatosan kísérletezett azzal, hogy a várostól húzott javadalmait valamiképpen növelje. 1768-ban - midőn számfeletti tanácsnoki állást kívánt szerezni - azt állította, hogy a tanterem bérletére 200 forintot kell fizetnie saját béréből. ${ }^{67}$

\section{A város és jogászprofesszora}

A város sokáig elégedett volt Perghold tanári tevékenységével, ${ }^{68}$ de midőn polgárjogért folyamodott 1763-ban a talán addig is lappangó feszültségek a felszínre törtek a város és professzora között.

1763-ban ugyanis Perghold polgárjogot kért a városi tanácstól, de kérelmét elutasították. Ez történt újabb kérelmével is, mire a professzor a nádorhoz és a Helytartótanácshoz folyamodott, aminek következtében a várost jelentéstételre szólították fel. A város azzal indokolta a polgárjog megtagadását, hogy a jog megadásához általában

${ }^{66}$ GÁRDONYI, „Pest városi...”, 112. BFL PL Intimata a. a. 3608. Szlávy a tanácsnak szóló, 1767. július 4-én kelt utasítását közli BónIs György, Pest-Budai hivatali utasitások a XVIII. században, Budapest Főváros Levéltára forráskiadványai 6 (Budapest, 1974), 105-112. A vonatkozó 15. pont így szól: "Quandoquidem aeque publice notum sit, juris civilis per hanc civitatem fundati auditores frequentius in popinis graves excessus commississe et ad verbera cum opificibus dominorumque servitoribus devenisse; istud vero inde evenerit, quod juvenes absque omni delectu et signanter tales etiam, qui ex academiis et gymnasiis tanquam discoli et inemendabiles absque testimonialibus amandantur, professor juris passim receperit. Ideoque usque dum plura suo loco circa regulationemm hujusce studii disposita fuerint, commissionaliter statuitur, ut memoratus juris professor auctoritate propria (exceptis tamen e magnatum aut conspicue nobilitatis prosapia artis) neminem ad studium juris recipiat, verum teneatur juris candidatos fine exhibendarum testimonialium ad dominum judicem civitatis mittere, quo idem dominus judex eos, qui de anteactae vitae probitatet ac profectu in literis sufficiens testimonium produxerint, admittere, eos vero, qui testimonialibus carent, vel iis notati sunt, arcere possit, de quo jam etiam professor juris per commissionem regiam instructus est."

${ }^{67}$ GÁrdonyI, „Pest városi...”, 114. BFL PL Intimata a. a. 4298.

${ }^{68}$ Perghold a következő két titulust használta pesti jogtanárként: 1763 és 1766 - U. J. Doctor, Imperialium Institutionum, Pandectarum, nec non et SS. Canonum Sacra-Caesarea-Regio-Apostolica Authoritate in Libera Regia Civitate Pesthiensi Professor Publicus Ordinarius. 1768 - Utriusque Juris Doctor, Ejusdemque Sacrae Caesareae, \& Regio-Apostolicae Majestatis Authoritate in libera Regia Civitate Pesthiensi Professor Publicus Ordinarius. 
elvárt négy előfeltétel közül egyik sem teljesül: Perghold nem pesti vagy hazai születésü, hanem Karintiából származik („Nec domesticus Patriae filius, sed natione carinthus [...]"); nincs háza vagy más ingatlana a városban; nem tudja letenni az ekkor szokásos, a közterhek viselését biztosító cautiót sem; és nem olyan mesterember, akinek foglalkozása miatt lenne fontos a polgárjog megszerzése, hiszen mint professzornak igazából sem a városnak sem neki magának nem áll érdekében a polgárjog megszerzése. Utóbb a kibontakozó vita hevében arra is hivatkozott a tanács, hogy Perghold szinte koldusként érkezett Pestre, már Bécsben is adósságokat hagyott hátra, és saját hibájából itteni javadalmai és mellékes keresményei sem elegendők életvitele költségei fedezésére, s így a közterhek viseléséhez sem járul és járulhat hozzá. ${ }^{69}$ Ezen alkalommal azt is felhozták Perghold ellen, hogy egyebek mellett ellenszegül a város rendeleteinek, tiszteletlen feljebbvalóival szemben, a tanácsot gúnyolja és állandóan vádaskodik a városvezetésre. Korábban erkölcstelenül viselkedő hallgatót is felvett tanulói közé, és csak a személynök közbenjárására volt hajlandó eltávolítani a tanulók közül. Nem tud fegyelmet tartani hallgatói között, és előttük a magyar nemzetet és annak törvényeit visszatérően becsmérli. Tulajdonképpen a polgárjog megadása helyett inkább hivatalából való elbocsátást érdemelne. ${ }^{70}$

Perghold ügye védelmében - második körben - arra hivatkozott, hogy még a pesti külső tanács tagjai között is vannak olyanok, akiknek nincs ingatlana a városban, azok sem iparosok és semmilyen adót sem fizetnek, tehát a tanács hibás érveket vonultatott fel kérelme elutasítása érdekében. Személyeskedésektől sem mentes előadmányában Perghold megtámadta a tanács döntését, azt feltételezve, hogy egyes tanácsosok attól félnek, hogy ő maga is tanácsnok akar lenni. Arra is hivatkozott, hogy saját könyveivel is kereskedik, s ezért akár még iparűzőnek is tekinthető lenne. Kijelentette, hogy ha nem pártolnák felvételi kérelmét - nem félve attól, hogy elbocsátják - a Helytartótanácshoz fog fordulni a városvezetés döntésével szemben. ${ }^{71}$

A városvezetés nagyon keményen reagált elégedetlen jogtanára fellépésére. 1763 decemberében arra kötelezték Pergholdot, hogy rövid határidővel mutassa be a hallgatók névsorát és erkölcsi bizonyítványait. Perghold válaszában ugyan megadta a névsort és szavatosságot vállalt tanítványai magaviseletéért, de a bizonyítványok kiadását megtagadta és hivatkozott arra, hogy a hallgatók bejelentése a szállásadók kötelessége lenne. Előadta, hogy mivel őt a hercegprímás tanulmányi főigazgatóvá nevezte ki, a városi tanács nem jogosult tevékenységét ellenőrizni. Az általa használt tankönyvre vonatkozó bemutatási kötelezettség alól azzal akarta kivonni magát, hogy csatolta korábbi beadványát saját tankönyve vonatkozásában, amit a tanács hallgatólagosan jóváhagyott. ${ }^{72}$

\footnotetext{
${ }^{69}$ MolnÁr, „Pest városának...”, 41. BFL PL Intimata a. a. 3608. GÁrdonYI, „Pest városi...”, 110.

${ }^{70}$ Uo.

${ }^{71}$ GárdonyI, „Pest városi...”, 109-110.

72 Gárdonyi, 110. BFL PL Intimata a. a. 3608.
} 
A tanács 1764 februári válaszában megrótta tiszteletlenségéért Pergholdot, a korábbiak megismétlése mellett további „vádpontokkal” gazdagította a tanár bűnlajstromát. Szemére vetette, hogy csak 24 hallgatót jelentett be, holott az általa benyújtott jegyzéken 43 név szerepelt. Összességében a tanács kinyilvánította, hogy elveszítette a jogtanárba vetett bizalmát, és a hallgatók erkölcsi előéletét maga a tanács kívánja a jövőben ellenőrizni. A tanács ugyanakkor visszautasította Perghold részrehajlásra vonatkozó vádjait és további jelentéstételre kötelezte a tanárt. ${ }^{73}$

Végül Perghold elkerülhetetlennek tartotta a Helytartótanácshoz fordulást, ami végül meg is történt. A központi kormányzat meglepetésre - persze megint csak alapos vizsgálat után - nem méltányolta a városvezetés részletes jelentésébe foglalt érveket és a polgárjog-adományozás ügyét Perghold javára döntötte el, aki így pesti polgárrá válhatott. ${ }^{74}$ Igy 1766-ban már adoptált pesti polgárként jelölhette magát. ${ }^{75}$

Az mindenesetre megállapítható, hogy a '60-as évek közepére az ellentétek jelentős mértékben kiéleződtek a város vezetése és Perghold között. Erre az időre a pesti származású hallgatók aránya lecsökkent, $s$ a város egyre kevésbé kívánta már vállalni az iskola fenntartásával járó anyagi terheket. ${ }^{76}$

\section{Az iskola bezárása}

A fent leírt előzmények után azt vélhetjük, hogy megegyezett a város vezetésének szándékaival a királynő 1771. augusztus 5-én kelt rendelete. Ebben az uralkodó leírta, hogy bár 1757-ben megengedte a jogi szakiskola működését, és annak igazgatását utóbb a Királyi Kúriára bízta, ${ }^{77}$ de a nagyszombati egyetem egyre erőteljesebb kiépítése szükségtelenné tette a pesti jogi szakiskolát. Hiszen itt mindössze csak egy tanár tanít, aki nem lehet képes egyedül a feladatok megoldására: mivel több tárgyat tanít, a hallgatók mindenből csak keveset tanulhatnak meg, de kellö alapossággal semmit sem sajátíthatnak el. Ennek fényében elrendelte az iskola bezárását, és a hallgatókat a nagyszombati egyetemre irányította. Pest város tanácsának azonban megparancsolta, hogy mivel Perghold erőit az intézetnek szentelte, az igazságosság és a méltányosság megkívánja, hogy a város egész életére biztosítsa jelenlegi fizetését és vagy tanácsossá választásával vagy más úton továbbra is adja meg neki járandóságát. Ha pedig a jogtanár meghalna, vagy más állásban nyerne alkalmazást, azt ajánlotta a városi tanácsnak, hogy jogi szakiskola helyett

73 GÁRDONYI, „Pest városi...”, 110-111. BFL PL Intimata a. a. 3608.

74 Molnár, „Pest városának...”, 41.

75 Több 1766-ban megjelent munkája címlapján jelölte így magát. Vö. lentebb.

${ }^{76}$ NAGY, „Budapest...”, 197.

77 „[...] quo etiam introducto ac ejusdem studii directione successive curiae nostrae Regiae per nos benigne deleta exstente [...]” Idézi MolNÁr, „Pest városának...”, 47. A kúriai felügyelet megvalósulását Fináczy 1770-re teszi, s úgy tudja, hogy ekkor tanrendi és fegyelmi szabályzatok is készültek, melyek jóváhagyása azonban már nem történhetett meg. Vö. FináczY, A magyarországi..., 140. 
fontolja meg bécsi mintára egy studium politico-camerale felállítását, és a jogtanár eddigi fizetését erre célra fordítsa. Ez annál is kívánatosabb lenne, mivel az államtudományok a városi tisztviselők számára hasznosabbak lehetnek a jogi tudományoknál. ${ }^{78}$

A megszüntetés mögött - kimondatlanul - nem a nagyszombati egyetem megerösödése és ezáltal a pesti iskola szükségtelenné válása húzódott meg, hiszen az 1755-ig szintén egy tanárt foglalkoztató egri Foglareanum továbbra is működhetett, igaz ekkor már három tanárral. Győrben, majd Pécsen, illetve Kassán ${ }^{79}$ továbbra is megmaradtak a jogi kurzusok, sőt utóbb katolikus jogakadémiákká lettek fejlesztve. Pest város jogi iskolájának csaknem 15 évi müködés utáni megszüntetése mögött sokkal inkább azok az ellentétek és feszültségek állhattak, melyek a tanács és az iskola jogtanára között az évek során szinte az ellenségeskedésig fajultak.

\section{Az iskola nélküli professzor}

Perghold, miután 1771 augusztusában közölték vele a királyi rendelet tartalmát, vagyis hogy az iskolát 1771. szeptember 7-ével bezárják, és hallgatóit Nagyszombatba irányítják, ő maga azonban továbbra is megkapja illetményét, nem tett eleget a királyi rendeletnek $s$ még ezután is nyilvános vitát rendezett tanítványai számára ${ }^{80}$ Ráadásul fel is jelentették Bécsben, hogy a vita alkalmából kinyomtatott tézisekben felforgató gondolatokat fogalmazott meg. Erre az uralkodó és a Helytartótanács 1771 decemberében vizsgálatot rendelt el a pesti tanácsnak címzett leiratában, amelyet a város vezetése rövid úton azzal válaszolt meg, hogy az iskola bezárásra került, és az nem működik, Perghold pedig magánúton sem tanít. A Helytartótanács nem elégedett meg a válasszal, hanem 1772 februári leiratában követelte, hogy a tanács dorgálja meg Pergholdot, aki nem jogosult sem nyilvános előadások tartására, sem magánoktatás folytatására. A professzor engedetlenségét súlyosbítja az is, hogy a legutóbb kiadott Thesisekben az uralkodóval szemben tiszteletlen hangot ütött meg. Figyelmezteti a tanácsot, amennyiben Perghold a későbbiekben ismét könyvet kívánna kiadni, azt köteles legyen előzetesen a cenzornak bemutatni. A leirat a magistratust is figyelmeztette gondatlansága miatt és utasította, hogy a jövőben semmi olyan nyomdaterméket ne engedjen sajtó alá, amit a cenzor a szokott módon nem vizsgált meg. ${ }^{81}$

Perghold az iskola bezárásával munkanélkülivé lett ugyan, de nem vált földönfutóvá, mivel az említett királynői rendelet szerint eddigi járandóságát továbbra is megkapta,

${ }^{78}$ GÁrdonyI, „Pest városi...”, 112. BFL PL Intimata a. a. 3608. MolnÁR, „Pest városának...”, 45. Fináczy, A magyarországi..., 141.

79 Az említett intézményekre vö. Juhász Réka Ibolya, „A magyar felsőoktatás egy fontos intézménycsoportja. A királyi jogakadémiák forrásai és feldolgozásának lehetőségei (1777-1850)”, Gerundium Egyetemtörténeti közlemények 7, 1-2. sz. (2016): 121-132.

${ }^{80}$ Vö. lentebb.

${ }^{81}$ GárdonyI, „Pest városi...”, 113. MolnáR, „Pest városának...”, 44-45. 
sőt egy olyan lehetőség nyílt meg előtte, amely már korábban is felmerült benne. Ugyanis Perghold már 1768-ban az udvari kancelláriához folyamodott, hogy az támogassa azon törekvésében, hogy Pest város számfeletti tanácsnoka lehessen. Ezen beadványában is arra panaszkodott, hogy fizetéséből nem tud megélni, és egyébként is sok az öreg tanácsos, akik nem tudnak az üléseken részt venni. A kancellária által közvetített kérés nyomán a város vezetése azt a megállapítást tette, hogy Perghold a beiratkozási díjak beszedése mellett napi néhány órai munkával keresi meg évi 504 forintját, míg a városi tisztviselők 300 forintért egész nap dolgoznak és nincsen mellékes keresményük. Utaltak arra is, hogy már jelölték Pergholdot tanácstagnak, de nem szavaztak neki bizalmat. Ha a tanácsban alkalmilag üresedés támad, akkor a külső tanácsból hívnak be helyetteseket, így számfeletti tanácsnokra nincs szükség. ${ }^{82} \mathrm{~A}$ kancelláriának küldött válaszban pedig kiemelték, hogy nincs üresedés a 12 tanácsnok sorában, és a tanácsnoki állás egyébként is összeegyeztethetetlen a professzori hivatással, mivel a tanácsosok idejét igencsak igénybe veszik az ülések és a kiküldetések, ami ütközne a tanítási idővel. Perghold egyébként pedig azért nem tud megélni fizetéséből, mert költekező életet él. A kancellária elfogadta a város érveit. ${ }^{83}$

Az iskola bezárása azonban feltámasztotta Perghold törekvéseit, és kérését megismételte. A város vezetése arra hivatkozott, hogy a tanácsnokok választása a választott polgárság joga, és a tanácsnak csak jelölési joga van. Megígérték azonban, hogy a következő alkalommal Pergholdot is jelölni fogják. Ez meg is történt, de 1773 áprilisában csak a választott polgárok közé jutott be a volt professzor. ${ }^{84}$

Perghold a célját végül 1777-ben érte el, amikor a György napi tisztújítás alkalmával megválasztották városi tanácsosnak. ${ }^{85}$ Tanácsnoki javadalma azonban csak 400 forint lett volna, ő azonban ragaszkodott eddig húzott fizetéséhez. Megint csak hosszú iratváltás után érte el Perghold a kancellária közbenjárására, hogy megtarthassa eredeti javadalmát. ${ }^{86}$

Igen ám, de az eddig Perghold fizetésére fordított járványalapot a Helytartótanács lefoglalta és ekkortól azt az elemi iskolák fenntartására fordították, ${ }^{87}$ tehát a városnak a Pergholdnak járó többletet máshonnan kellett előteremtenie.

Perghold tanácsosi tevékenysége sem volt konfliktusmentes, többször szembekerült egyes ügyekben a tanács többi tagjával és magával a testülettel. A fennmaradt jegyzőkönyvekből kitűnőleg fennhéjázóan hangoztatta nagyobb tudását, és igazságérzetére hivatkozva nyilvánosan is bírálta a tanács döntéseit. Megintések és figyelmeztetések

${ }^{82}$ GÁrdonyI, „Pest városi...”, 114.

83 GÁRdonYI, „Pest városi...”, 114. BFL PL Intimata a. a. 4298.

${ }^{84}$ GÁrdonyI, „Pest városi...”, 114. Tanácsülési jegyzőkönyv 1773. április 23. Schmall, Adalékok..., 155.

85 Schmall, Adalékok..., 180. Professori titulusát végig megtartotta.

${ }^{86}$ GÁrdonYI, „Pest városi...”, 115. BFL PL Intimata a. a. 5320.

87 „[...] ut fundus ille 500 florenorum, qui prius juris civilis professori Berchtoldt solvebantur, pro scholis normalibus applicetur [...]”. GÁRDONYI, „Pest városi...”, 115. BFL PL Intimata a. a. 5343. 
kísérték fellépéseit, ami elsősorban abból adódott, hogy többször szembe ment a tanács egyes határozataival, és ezáltal megbontotta a tanács addig legalább kifelé mutatott egységét. A korabeli iratok szerint sok személyes ellenséget (pl. Papics és Hülff polgármesterek, Mosel tanácsnok, volt polgármester) szerzett önfejü és saját értékrendjét követő magatartásával ${ }^{88}$ Tudálékos megjegyzéseivel, vitatkozásaival késleltette az ügyek elintézését, sőt - megszegvén esküjét - a tanácsban történteket a külvilág számára is megszellőztette, ${ }^{89}$ vádaskodásaival a központi hatóságokat is felkereste, a bizonyítékul szolgáló iratokat magánál tartotta.

A korabeli tanácsülési jegyzőkönyvekben több kellemetlen ügy szereplőjeként tűnt fel a rendbontó egykori professzor. Több peres ügye volt részben hivatali tevékenységéből, részben magánügyekből kifolyólag. ${ }^{90}$ Hatalmi túlkapás miatt még elzárásra is ítélték 1784-ben. ${ }^{91}$ A következő évi tisztújításkor - valószínűleg a Pergholdtól kapott információk hatására - a választást felügyelő királyi biztos (Josephus Lányi királyi jogügyigazgató) az uralkodó rendeletére a tanács tagjainak nagyobb részét megvesztegetés gyanújával elmozdította pozíciójából. ${ }^{92}$ Perghold maradhatott volna tanácsos, de a választást elvesztette, időlegesen azonban továbbra is részt vett a csonka tanács munkájában egészen 1787-ig. ${ }^{93}$ Perghold a '80-as évek közepén - kihasználva II. József azon törekvéseit, hogy a városok belügyeibe is mindjobban beavatkozzon - a saját pecsenyéjét sütögette a tanáccsal szemben, és ezzel az uralkodói politikát szolgálta. Ezt mutatja a királyi jogügyigazgató eljárása is. ${ }^{94}$

Perghold, mint pesti tanácsnok 1787. március 1-jén vonult „nyugdíjba”. A 18. században ez volt az első és egyetlen eset Pesten, hogy valaki nyugalomba vonulhatott, hiszen addig a tanácsosi szolgálat élethosszig tartott, és lehetetlen volt az, hogy valaki szolgálatra képtelensége esetén továbbra is fizetést kapjon a várostól. Perghold évi 504 forintos „nyugalomdíja” tehát rendkívülinek tekinthető. ${ }^{95}$

„Nyugdíjas éveiről” nem maradt fenn adat, 1792-ben hunyt el. Halála után könyveit nyilvános árverésre bocsátották. Ezt egy possessori bejegyzésből tudjuk, mely szerint

${ }^{88}$ Bónis, „Városigazgatás...”, 185.

${ }^{89}$ Kovács Lajos, „Pest szabad királyi város vezetői (bírái és polgármesterei) 1687-től 1790-ig”, Tanulmányok Budapest Múltjából 10 (Budapest: A székesfőváros kiadása, 1943), 87.

90 A Wienerisches Diarium 1764. április 11-i 29. száma szerint Perghold ügyfele volt Andreas Gottfried Platischa, J.U.Doctor, Hof- und Gerichts-Advokatnak Bécsben.

${ }^{91}$ Néhány ügyet ismertet GÁRdonYI, „Pest városi...”, 116. Kovács, „Pest szabad királyi város...”, 93-94. BóNIs, „Városigazgatás...”, 175.

92 Kovács, „Pest szabad királyi város...”, 96-97. Magyar Nemzeti Levéltár Országos Levéltár, Helytartótanácsi levéltár, Departamentum politiae in genere et civitatum 1785. f. 44.

93 Gárdonyi, „Pest városi...”, 116-117. Kovács, „Pest szabad királyi város...”, 93-94.

${ }^{4}$ Kovács, „Pest szabad királyi város...”, 88. II. József városigazgatási törekvéseinek pesti hatásáról, benne Pergholdnak mintegy az uralkodó védőszárnya alatt végzett tevékenységéről vö. Kovács, „Pest szabad királyi város...”, 90-100.

95 BFL PL Intimata a. a. 768. Vö. Schmall, Adalékok..., 110. Márher Aladár, „A közszolgálatban alkalmazottak nyugdíjszerủ ellááása, Városi Szemle 3 (1910): 427. GÁrdonYI, „Pest városi...”, 117. 
egyik könyvét, Jean Bodin művének egy kivonatát, ezen az aukción a Nemzet Múzeum későbbi igazgatója Jacob Ferdinand Müller vásárolta meg, s a kötet később a debreceni egyetem könyvtárának tulajdonába került. ${ }^{96}$

\section{Perghold müvei}

Perghold viszonylag termékeny szerzőnek tekinthető. Nyomtatott munkái és egy ma ismert kéziratos műve - egy kivételével - a pesti jogi szakiskola élén töltött időszakban keletkeztek. Miután megszűnt az iskola, „tudományos” munkássága is elapadt, élete hátralévő húsz évében már nem publikált. Az elnöklete alatt megvédett thesiseket nem számolva hat eredeti művét és egy szövegkiadását veheti számba az utókor. ${ }^{97}$

Perghold eredeti munkáinak egyik tartalmi jellemzője, hogy tételes jogi munkáiban, de különösen „jogelméletinek” tekinthető jogi értekezéseiben teljes mértékben szembe ment kora „mainstream” jogi felfogásával, a természetjogi iskola által hirdetett tanokkal. Feltűnő indulatossággal és korántsem mindig szakmai érvekkel támadta százada neves vagy kevésbé neves jogi szerzőinek gondolatait. Az általa „cultores naturalistae”ként aposztrofált jogi írókat a saját maga által elnevezett „deista” álláspontból opponálta egyrészt a házassági jog területén, másrészt bizonyos elméleti kérdésekben. Műveiből kitűnően Perghold olvasottsága jelentős volt az antik szerzők és az egyházatyák terén, ismerte az alapvető protestáns hittételeket is, de igazán jól az Ó- és Újszövetségben ismerte ki magát. A jogi szerzők terén jártassága nem tekinthető kiemelkedőnek.

Formai szempontból sajátossága Perghold irodalmi munkásságának, hogy csekély kivételtől eltekintve tanítványai (vagy más a hatókörébe került hallgatók) nyilvános vitatkozásokra nyomda alá bocsátott tézisfüzeteit használta fel arra, hogy saját munkáját azokhoz hozzácsatolja és így adja ki, akár korábban már megjelent művei újabb kiadása céljából is.

Ezen megoldással csökkentette (talán helyesebb úgy fogalmazni, teljesen vagy részben átvállaltatta) munkái kiadási költségeit, másrészt a munkák szélesebb körű elterjedését is biztosíthatta, bár ekkoriban a hasonló jellegű munkák nem jelentek meg néhány százas nagyságrendnél nagyobb példányszámban. Ez az eljárás meglehetősen elterjedt volt ebben a korban, nem csak Perghold élt ezzel a lehetőséggel. Az alábbiakban utalni fogunk az ezen az úton megjelent kiadásváltozatokra is

1. Mai tudásunk szerint Perghold első nyomtatásban megjelent munkája a poligámiáról, vagyis a többes házasságkötésről szólt. A több mint 200 oldalas munkát 1755-ben

96 OJtozı Eszter, „Ex librisek a Debreceni Egyetemi Könyvtár XVII. századi külföldi könyveiben”, A Debreceni Déri Múzeum Évkönyve 1994 (Debrecen, 1996), 331. A bejegyzés így szól: „Comp. in actione publica Librorum Cl. Lucae Perghold Juris Doct. et in Lib Reg. Civit. Pestiensi Senatoris. Peatini. J. Ferdinand de Miller".

${ }^{7}$ Szinnyei összesen hét munkáját sorolja fel, amelyek között egy Thesis is helyet kapott. SzInNyeI, Magyar irók... 10, 779-780. 
adták ki először önállóan, ${ }^{98}$ de utóbb még kétszer megjelent 1766-ban és 1771-ben. Utóbbi két esetben Perghold nyilvános vitairatok kísérőjeként gondoskodott műve kiadásáról. Előbb (1766 szeptember) egyik joghallgatója, „Martinus Mihálkó Civis Hungarus Budensis" vegyes jogi téziseket oldalszámozás nélkül felvonultató munkája mellé járult Preghold írása. ${ }^{99}$ Második ízben (1771. április) pedig három minorita szerzetesnövendék nyilvános teológiai vitatkozását használta ki munkája terjesztéséhez. ${ }^{100}$

Művében történeti példák felidézésével helyezkedik szembe mindenféle, a többnejüségre vonatkozó engedékenységgel (pl. morganatikus házasság), és elsősorban teológiai, bibliai és ókori irodalomból vett érvekkel támadja hevesen a természetjogászokat (naturalistas - különösen Michael Henricus Gribnerust), akik szerinte elnézők a kettős házassággal szemben.

2. Perghold valószínüleg legnagyobb hatású, nyomtatásban megjelent munkája egy tankönyvsorozat volt, amelyben a iustinianusi Institutiókat magyarázta, és amelyet mint láttuk - az első évfolyamos hallgatóinak szánt bevezető tankönyvül. Ennek első három kötete 1757-ben jelent meg. ${ }^{101}$ Ezeket Johann Gerhard Mauss nyomdász nyom-

${ }^{98}$ Polygamiae, sive Simultanae Uxorum Pluralitatis Damnabilitas secundum ipsum Jus Naturae pro Fide, Lege, Principe, Veritate adversus Fabricatores Mendacii et Cultores Perversorum Dogmatum Naturalistas, Demonstrata a Paulo Luca Perghold, U. J. Doctore Typ. Eizenberger, 1755.

99 Polygamiae, sive Simultanae Uxorum Pluralitatis Damnabilitas secundum ipsum Jus Naturae pro Fide, Lege, Principe, Veritate adversus Fabricatores Mendacii et Cultores Perversorum Dogmatum Naturalistas, Demonstrata a Paolo Luca Perghold U. J. Doctore Carniolo, Adoptione Hungaro Cive Pestano. Pestini, Typis Eitzenbergerianis, MDCCLXVI. \{külön címlappal oldalszámozás nélkül hozzáfüzve\} dum [...] ex Jure Divino Naturae, Gentium, Hungarico-Canonico-Civili, Feudali, Criminali, et Pro Parte Publico Generali Selectas Theses Praeside Paulo Luca Perhold U. J. Doctore Imperialium Institutionum Pandectarum, nec non et SS. Canonum Sacrae, Caesareae.\& Regio-Apostolica Majestatis Authoritate in Libera Regia Civitate Pestiensi Professore Publico Ordinario, Publice per triduum propugnavit [...] Martinus Mihálkó Civis Hungarus Budensis, ac Jurium in Primum Annum Auditor. Pestini Die

Mensis Septembris Anno 1766. Typis. Eizenbergerianis, 1766.

De ugyanebben az évben Martinus Csombó tézisfüzetéhez is hozzákötötték ezt a munkáját. Vö. A füleki ferences rendház régi állománya. Katalógus. Összeáll. MARTí Tibor. A Kárpát-medence magyar könyvtárainak régi könyvei 7. (Eger: Eszterházy Károly Főiskola, 2012), 384.

100 Polygamiae, sive simultanae uxorum pluralitatis damnabilitas secundum ipsum jus naturae pro fide, lege, principe, veritate adversus fabricatores mendacii et cultores perversorum dogmatum demonstrata, quam [...] publico donat author Paulus Lucas Perghold [...] (dum... de augustissimo [...] Trinitatis mysterio Theses Theologicas [...] Budae in Ecclesia honori Divi Patriarchae Francisci [...] signis signali [...] publice propugnandas suscipiunt die 28. mensis Aprilis religiosi p [atres] [...] Ordinis Minorum Regularis Observantiae [...] Antonius Jelicsich [...] Liborius Laczkoczi et Simon Krantz [...] theologiae studentes generales, sub assistentia [...] Ladislai Spaics). Budae in typographia Landereriana, [1771]. Vö. Pavercsik Ilona, Magyarország bibliográfíja 1712-1860, VII. Pótlások (Budapest: Országos Széchenyi Könyvtár), 400.

101 Methodica In I[-III]. Sacratissimi Principis Justiniani Institutionum Librum Commentatio Nobilis Hungaricae Juventutis Usui Accommodata A Praenobili, Clarissimo, ac Consultissimo Viro Paulo Luca Perghold, U. J. Doctore, Ejusdemque Caesareo-Regia Authoritate In Libera - Regia Civitate Pestiensi Professore Publico Ordinario. Budae, Prostant Pestini Typis Leopoldi Francisci Landerer, Apud Authorem, Et Mauss Bibliop. M.DCC.LVII. Petrik Géza, Magyarország bibliográfíja 17121860, III. (Budapest: Dobrowsky, 1891), 70. 
tatta ki Pesten, és ez tekinthető az első, ebben a városban kinyomtatott szakkönyvnek. A könyv 1757. március 27-én kelt előszava a művet Pest város tanácsának ajánlotta. ${ }^{102}$ A negyedik kötet 1758-ban követte az előzőket Leopold Landerer sajtója alól. ${ }^{103}$ A tankönyvsorozat második kiadása szintén négy kötetben, 1766-ban jelent meg. ${ }^{104}$ Az első kötet esetében Perghold itt is kihasználta, hogy egyik tanítványa nyilvános vitára bocsátotta téziseit, és ezekkel együtt adatta ki Landererrel saját tankönyve elejét is. ${ }^{105}$

Az összesen csaknem ezer oldalas kommentárfolyam tulajdonképpen egyetemi szinten kommentálja az ókorból fennmaradt, alapvető jogi ismereteket tárgyaló tankönyvet, amelynek anyaga valamennyi európai jogi karon - általában külön professzor által előadva - a curriculum alapvető részét képezte. ${ }^{106}$

3. Perghold legfontosabb közjogi munkája De rege et cive eorumque mutuo officio címmel először 1761-ben jelent meg, de - mint láttuk - egy 1754-ben készült kéziratra (De Officio Civium Rege ejecto) ment vissza, ${ }^{107}$ amelyet a bécsi egyetemre pályázva írt. Ezt a munkát, amely 278 oldal terjedelmű volt, Perghold egyik tanítványa Szkatsányi János adatta ki annak emlékéül, hogy 1761 szeptemberében három napon keresztül nyilvánosan vitatkozott (Theses ex Universo Jure delectas). ${ }^{108}$ Ugyanez a munka 1766-ban

102 Pavercsik Ilona, „Johann Gerhard Mauss és a pesti könyvkereskedelem színvonala a 18. század közepén I.”, Magyar Könyvszemle 106, 1-2. sz. (1990): 126-127. GAZDA István, „A szakkönyvkiadás kezdete Pesten (1748-1798)”, Technikatörténeti szemle 20 (1993): 159. GAZDA István, „Az első ötven év. Könyvkereskedők, könyvkiadók, nyomdászok Pesten 1748-1798 között, különös tekintettel az általuk kiadott reáltudományi munkákra”, Kaleidoscope 9, 17. sz. (2018): 426. Mausst egyébként Perghold művei letéteményesének tekintik egyes szerzők. Vö. NAGY, „Budapest...”, 202. Ugyanakkor Perghold más nyomdásszal (Landerer, Eitzenberger) is dolgoztatott és maga is árulta könyveit. PAVERCsiK, „Johann Gerhard Mauss...”, 127.

103 Methodica In IV. Et Ultimum Sacratissimi Principis Justiniani Institutionum Librum Commentatio Nobilis Hungaricae Juventutis Usui Accommodata A Praenobili, Clarissimo, ac Consultissimo Viro Paulo Luca Perghold, U. J. Doctore, Ejusdemque Caesareo-Regia Authoritate In Libera Regia Civitate Pestiensi Professore Publico Ordinario. Budae, Prostant Pestini Typis Leopoldi Francisci Landerer, Apud Authorem, Et Mauss Bibliopolam. MDCCLVIII. Petrik, Magyarország..., III. 70.

104 Methodica in I[-IV]. Sacratissimi Principis Justiniani Institutionum Librum Commentatio Nobilis Hungaricae Juventutis Usui Accomodata ac Perennibus Mariae Christinae et Alberti Augusti Serenissimorum Regiorum Principum Honoribus a Paulo Luca Perghold, U. J. Doctore Carniolo, Adoptione Hungaro Cive Pestiensi. Budae Typis Leopoldi Francisci Landerer, MDCCLXVI. KoмJÁTHY Miklósné, Magyarország bibliográfiája 1712-1860, V. Pótlások (Budapest: Országos Széchenyi Könyvtár, 1971), 384.

${ }^{105}$ Dum eorundem sub clementissimis Mariae Christinae et Alberti Augusti [...] auspiciis ex Jure Universo, hoc est ex Jure Divino, Naturae, Gentium, Hungarico, Civili, Canonico, Criminali, Feudali, nec non Publico generali Selectas Theses Praeside [...] Paulo Luca Perghold, [...] Imperialium Institutionum [...] in [...] civitate Pesthiensi professore [...]; publice per triduum propugnaret ... Martinus Csombo [...] U. J. Auditor emeritus, Pesthini [...] 1766. [Budae], [Typ. Landerer], [1766]. Комје́тну, Magyarország..., V. 384.

106 Többek mellett vö. Karl Heinz Burmeister, Das Studium der Rechte im Zeitalter des Humanismus im deutschenechtsbereich (Wiesbaden: Pressler, 1974), 119-129.

107 Lásd fentebb az 1761-es kiadás előszavát.

108 Perghold, De Rege..., 1761. Petrik, Magyarország..., III. 70. 
ismét megjelent Albert hercegnek ${ }^{109}$ és Mária Krisztina főhercegnőnek ajánlva, és szintén társítva egy Perghold-tanítvány tézisfüzetéhez. ${ }^{110} \mathrm{~A}$ munkát azután harmadszor is kiadta 1771-ben, éppen a jogi szakiskola fennállásának utolsó napjaiban, szintén egy tanítványa vita-téziseihez kapcsolva. ${ }^{111}$

A két nagyobb egységre osztott, csaknem 300 oldalas munka első részében a királyság intézményéról értekezik: történeti, politikai és kisebb részben jogi fejtegetésekben foglalkozik a királyság intézményének eredetével és szükségszerüségével, a királyi felségjogokkal és méltósággal, valamint az uralkodók hatalmi eszközeivel. Vezérfonalul elsősorban az Ószövetség, a régi és újabb történetírók művei, valamint Johannes Bodinus (Jean Bodin), Justus Lipsius, Hugo Grotius munkái, illetve néhol az utóbbiakkal szembeni kritika szolgálnak. Az értekezés második részében a polgári státuszról, a polgárok békeidőben, háborúban illetve zendülés idején tanúsítandó - uralkodóval szembeni kötelezettségeiről, illetve az országból esetleg az ellenség által elűzött uralkodóval szembeni hűségről elmélkedik. A munkában néhányszor utalás történik a hazai viszonyokra, a Habsburg-ház és Mária Terézia uralkodására is, de mindig a legnagyobb alázattal és tisztelettel, amit egyébként már az ajánlás is tükröz. ${ }^{112}$

Eddig nem volt módunk verifikálni a munka 1771-es, harmadik kiadásához kapcsolódó, Pergholddal szemben felhozott azon „vádat”, hogy ebben a változatban -

109 Albert életére és magyarországi szerepére vö. Krisztina Kulcsár, „Ein fremder Adeliger zwischen der Königin und den ungarischen Ständen. Der Lebenslauf von Prinz Albert von Sachsen bis 1765 und seine Ernennung zum Statthalter des Königreichs Ungarn”, in Gabriele HaUg-Moritz und Hans Peter Hye und Marlies Raffler, Hg., Adel im "langen” 18. Jahrhundert, Zentraleuropa-Studien 14 (Wien, 2009) 275-288.

110 De Rege et Cive, Eorumque Mutuo Officio Opus Christiano-Juridico-Politicum Observationibus Historicis, Criticis, Moralibus, et Polemicis Illustratum, ac Perennibus Mariae Christinae et Alberti Augusti Serenissimorum Principum Honoribus. A Paulo Luca Perghold, U.J. Doctore, Carniolo, Adoptione Hungaro Cive Pestiensi. Budae, Typis Leopoldi Francisci Landerer Typographi, 1766. Gárdonyi úgy látta, hogy a munka Martinus Csombó tézisfüzetéhez kapcsolódott. Ez lehetséges, de a könyvészeti adatok jelenleg nem igazolják. Vö. GÁrdonYI, „Pest városi...”, 113.

111 Paulus Lucas Perthold, De rege et cive eorumque mutuo officio. Opus Christiano-Juridico-Politicum, Observationibus historicis criticis, moralibus et polemicis illustratum, auditoribusque oblatum, dum sub clementissimis beatissimae virginis matris Mariae verae apostolici Hungariae regni [...] auspiciis ex Universo Jure Selectas Theses propugnavit [...] Thomas Orlandini. Pesthini, Typis Eitzenberger, 1771.

${ }^{112}$ Az 1761-es szöveg áttanulmányozása során nem találtuk igazolását annak az újonnan megjelenő állításnak, hogy Perghold a munkában a rendi szabadságok védelmezőjeként lépne fel. Vö. Joachim BAHLCKE, Ungarischer Episkopat und österreichische Monarchie. Von einer Partnerschaft zur Konfrontation (1686-1790). (Stuttgart: Franz Steiner Verlag, 2005), 280. Bahlcke valószínúleg egy általa röviden ismertetett kézirat alapján prejudikál. Szerinte három évvel később Perghold ugyanis hasonlóan kritikusan nyilatkozott a terjeszkedő központi hatalommal szemben egy csak kéziratban fennmaradt munkájában (Libellus apologeticus), amelyben Adam Franciscus Kollar uralkodó párti nézeteivel szállt szembe és Kollárt Macchiavelli tanítványának nevezte. Vö. Libellus apologeticus, In quo Adversus Adami Francisci Kollarii Libellum singularem De Originibus et usu Perpetuo Potestatis Legislatoriae circa sacra ..., Pestini, 1764. 8. A kézirat fellelhető: Esztergom, Főszékesegyházi Könyvtár. Talán Fináczyt (lasd alább) követve Bahlcke is vélelmezi, hogy Pergholdnak a kormány egyházakkal szembeni politikáját bíráló magatartása is hozzájárult az iskola bezárásához. BAHLCKE, Ungarischer Episkopat..., 280-281. 
megtévelyedve - az uralkodóval szemben tiszteletlen állításokat fogalmazott volna meg. Perghold állítólag olyan kijelentésre ragadtatta magát, hogy a koronázás és az egyházi felkenés abban az esetben is elengedhetetlen elöfeltétele a törvényes uralkodásnak, ha egy az uralkodó család által dinasztikusan uralt országról van szó. A vádlóként fellépő kancellária tanácsosai - Fináczy szerint - tagadták az egyházi felkenés szükségességét, ${ }^{113}$ és azzal vádolták Pergholdot, hogy a világi hatalom függetlenségét istenkáromlásként beállítva „sötét és veszedelmes tanokat” hirdet. Javasolták, hogy tanári állásából mozdítsák el, mivel félrevezeti az ifjúságot és jelentős károkat okoz tevékenységével. Mint tudjuk az iskola bezárásával ez meg is valósult, és a városi tanács is megkapta a magáét a cenzúra elmulasztásáért. ${ }^{114}$

Ez a megközelítés annál ellentmondásosabb Perghold vonatkozásában, mivel más, a Habsburg-házzal egy kicsit is szembe menő megnyilatkozásának - a fentebb említettet kivéve - nincs nyoma, és II. József alatt - városi politikusként - igencsak a kalapos király központosító törekvéseit látszott szolgálni. ${ }^{115}$

4. A megszokott módon Perghold kihasználta azt a lehetőséget, amit Georgius Jankovics 1763-ban tartott nyilvános vitája adott arra, hogy megjelentesse egy házasságról írott munkáját (De sponsalibus), ami nem kevesebb, mint 413 oldal terjedelmű volt. ${ }^{116}$ Ugyanezt megjelentette változatlan tartalommal 1766-ban is, s ez utóbbi munkát is Albert hercegnek ajánlotta, mintegy házasságkötése alkalmából. ${ }^{117}$ Utóbb Kalocsán is

$\overline{113}$ „Ki tagadhatja, hogy Felséged a koronázás elött is Magyarország és Csehország jog szerinti királynéja volt? Az egyházi és világi hatalom határvonalait maga az Isten állapitotta meg teljes világossággal; ha pedig az egyházi hatalom az ország fejedelmeinek jogaiba bele akarna avatkozni (a mi sajnos, már többször is elófordult), akkor minden józan hittudós és jogász meg fogja engedni, hogy a világi hatalom tiszte ilyes esetekben az egyházi hatalomnak ellent állani és e végböl ennek tetteibe betekintést követelni." A kancellária álláspontját saját fordításában közli FinÁczY, A magyarországi..., 140-141.

114 Fináczy, A magyarországi..., 141.

115 Talán ezt igazolja az is, hogy egyes adatok szerint a '80-as években, még nyugalomba vonulása előtt Perghold látta el a cenzori feladatokat a városi tanács megbízásából. BFL PL Intimata a. a. 6364. Vö. SAshegyi Oszkár, „Zensur und Geistesfreiheit unter Joseph II. Beitrag zur Kulturgeschichte der Habsburgischen Länder" Studia historica Academiae Scientiarum Hungaricae 16 (1958): 56. VÁRNAI Sándor, „A hazai könyvnyomdászat múltjából V.”, Magyar Nyomdászat 21, 12. sz. (1908): 388.

116 Pauli Lucae Perghold, U. J. Doctoris De Sponsalibus, Matrimonii impedimentis, Matrimonio, ac ejus indissolubilitate vel secundum ipsum Jus Naturae adversus Naturalistas apologetici libri III. Pro Fide, Lege, Principe, Veritate, editi cum sub gratiosissimis Auspiciis [...] Francisci e comitibus Barkoczi de Szala [...] ex Universo Jure Selectas Theses Publice data cuilibet liberrima opponendi facultate propugnaret Pestini die __ September Anno 1763. Nobilis, Generosus, Ac Perdoctus Dominus Georgius Jankovics, U. J. Auditor Emeritus, nec non Inclytae Tabulae Regiae Judiciariae Notarius Juratus, Typis Leopoldi Francisci Landerer, typographi, [1763].

117 De Sponsalibus, Matrimonii Impedimentis, Matrimonio, ac ejus Indissolubilitate, vel secundum ipsum Jus Naturae Adversus Naturalistas Apologetici Libri III. Pro Fide, Lege, Principe, Veritate. Perennibus Mariae Christinae et Alberti Augusti serenssimorum Regiorum Principum Honoribus A Paulo Luca Perghold U. J. Doctore, Carniolo, Adoptione Hungaro Cive Pestiensi. Budae, Typis Leopoldi Francisci Landerer, MDCCLXVI. КомJáthy, Magyarország..., V. 384. 
megjelent a mủ 1768-ban, amikor is Perghold egy papnövendék nyilvános vitatéziseihez füzette hozzá azt. ${ }^{118}$

Perghold előbb a házasság (sponsalia) szó etimológiáját, a házasság mint jogi jelenség fogalmát járja körül, a római jog házasságfelfogásból kiindulva, de elsősorban a kánonjog és a Tridentinum elveit előtérbe állítva. Majd részletesen, viszonylag szoros jogászi gondolatmenettel a házassági akadályokról értekezik sok történeti példát felvillantva. A vérrokonok közötti rokonsági fok számítást (computatio) számos ábrával érzékelteti, különböztetve a római jogi és kánonjogi számítás között. Ezen művében is jelentős erőket mozgat meg (meglehetős terjengősséggel) bizonyos természetjogi elvek és szerzők álláspontjának cáfolására, mivel azokat a jus Divinummal éles ellentétben állónak tekinti. A rokonsági akadály mellett (amit csaknem 150 oldalon fejteget) fontos szerepet kap másik kedvenc témája, a többes házasság is. Egyéb akadályokat is felsorol itt, köztük olyanokat is, amelyeket a modernebb házassági jog inkább a házasság érvénytelenségének okai között katalogizál. Harmadik nagy egységként (szintén mintegy 150 oldal) a házasság szentség-jellegének és felbonthatatlanságának kérdésébe bocsátkozik bele. Itt is bibliai, történelmi és irodalmi példákkal, az egyházi jogforrások citálásával próbálja védeni a katolikus elveket a természetjog (Thomasius, Heineccius, Gribnerus) „engedékenységével” szemben.

5. A hallgatói vitatkozásokhoz csatolás révén adatta ki egyéb munkáit is. Így egy rövidebb terjedelmű munkáját előbb 1763-ban egy joghallgató, ${ }^{119}$ majd 1765-ben három minorita szerzetes filozófiai tárgyú vitapontjaihoz csatoltatta hozzá. ${ }^{120}$

A törvények céljáról szóló ,jogelméleti” írásában (Diatriba christiano-politica de legum omnium fine laconice pertractata) Perghold különböző (többnyire nem jogász)

118 Pauli Lucae Perghold [...] De Sponsalibus, Matrimonii Impedimentis, Matrimonio ac ejus Indissolubilitate, vel secundum ipsum Jus Naturae adversus Naturalistas Apologetici libri III. Pro Fide, Lege, Principe, Veritate Auditoribus oblati, dum Assertiones ex Universa Theologia Anno 1768 mense Augusto in Metropolitana Colocensi Ecclesia publice propugnandas susciperet Joannes Bap. Németh [...] ex Praelectionibus Joannis Petras ... parochi Bezdanensis. Colocae 1768, typis ArchiEpiscopalibus per J. J. Wagner. КомJátнy, Magyarország..., V. 384.

119 Pauli Lucae Perghold, Diatribe de legum omnium fine laconice pertractata ac edita, cum selectas ex I. Imperialium institutionum libro theses Hungarico-canonico-civiles et pro parte feudales per incl. Hungariae regnum generali studiorum directore et protectore [...] Francisco e comitibus Barkoczi de Szala in primo menstruo exercitio propugnaret Nicolaus Piukovics, [...] Pesthini, die [?] mensis Martii, anno 1763. - Budae : typis Leopoldi Francisci Landerer, [1763]. Petrik Géza, Magyarország..., III. 101.

120 Diatribe de Legum Omnium Fine laconice pertractata \& per [...] Paulum Lucam Perghold Publicum Juris Civilis Doctorem edita, Diatribam Rationalis Philosophiae ad mentem Subtilis Principis Joannis Duns-Scoti, modernique aevi Doctorum, proponens, Quam sub faventibus Auspiciis Amplissimi Magistratus Hujus Liberae, Regia, \& Metropolitanae Civitatis Budensis ad Sacra D. Francisci Stigmata Propugnarunt Rel. FF. Marianus Lanossovich, Martinus Pereczky, et Cajetanus Haraszty Ord. Min. Observ. Prov. S. Joannis à Capistrano Clerici professi, \& Philosophiae Studentes Praeside Hieronymo Jakocsevich. Ejusdem Instituti \& Proivinciae in praefato Conventu Philosophiae Lectore Anno 1765. Die 12. Maji. Budae, Typis Leopoldi Francisci Landerer, Typographi Petrik, Magyarország bibliográphiája, II. (Budapest: Dobrowsky, 1890), 255. 
szerzők törvényfogalmait veszi számba az ókortól kezdődően, és ezen keresztül próbálja meg kibontani a törvények külső céljáról, hasznáról és jelentőségéről megfogalmazott saját álláspontját. A törvények külső célját a közösség békéjének szolgálatában látja, ${ }^{121}$ és szükségszerűnek, a közösség legfontosabb fenntartó eszközének tekinti, ${ }^{122}$ ugyanakkor végsősoron az Istentől támogatott uralkodótól származónak tartja. Az értekezés második fejezetében - a korábbiakhoz hasonló eszközökkel - a törvények belső célját kutatja, amit az igazság megvalósításában lát, így annak lényegét kívánja feltárni. Megállapítja, hogy az igazság csak akkor valósul meg, ha együtt jár a méltányossággal és kegyességgel (aequitas et clementia), s ennek biztosítása az uralkodó feladata az istentől ráruházott hatalomnál fogva. ${ }^{123}$

6. Következö rövidebb írása, Dissertatio paraenetica címmel 1768-ban kétszer is megjelent, előbb Martinus Járdoss elsőéves joghallgató nyilvános vitájához, ${ }^{124}$ illetve ismét budai ferencesek hittudományi vitatkozásához kapcsolódva. ${ }^{125}$

Ezen műve tulajdonképpen nem más, mint egy indulatos röpirat a természetjog tanai ellen, de még inkább a természetjog professzoraival szemben, ${ }^{126}$ akiket eretnekeknek,

121 „Leges velut Sol hujus universi, humanis actionibus depulsa erroris nube porrigunt, eas jacentes erigunt, stantes conservant. Per has pax populorum, tutamen Patriae, Gentium munimentum, quies publica, \& omnium rerum prosperitas comparatur, immo earum una benignitate obtinetur," PERGHOLD, Diatribe ..., $10-11$.

122 „Dignitatem Legis ipsa conjuncta utilitati depraedicat necessitas. [...] His Princeps subditorum suorum debet obedientiam: Sublimitas Majestatem: Placita hominum perpetuitatem: innocentia securitatem: Fides inviolabilitatem: Religio firmitatem: Sanctitas Sanctitaem." Perghold, Diatribe ..., 12-13.

${ }^{123}$ „Nos modo felices in nostris esse patiantur ditionibus, qui eam nostrorum e Christi longe alia disciplina nacti sumus moderatricem Mariam Theresiam Imperatricem Augustissimam, \& Apostolicam Reginam nostram ad unius Justitiae normam clementissimam, utpote in qua considerante semitas Domus suae Justitia, \& Clementia praecipuae RUdolPhINAE StIRPIS virtutes arcto adeo copulatae sunt vinculo [...]." Perghold, Diatribe ..., 65-66.

${ }^{124}$ Lucae Pauli Perghold U.J.D. Dissertatio Paraenetica ex qua Libertinismi, Indifferentismi, omnisque, quae multiplicata per orbem, malitiae, praecipua, quibus verbum Domini factum est in opprobrium, cerebrini aevi nostri Doctores, fabricatores mendacii \& cultores perversorum dogmatum Naturalistae dignoscentur esse causa. Auditoribus Oblata cum sub illustrissimi Domini Comitis Joannis Illésházy de eadem [...] gratiosissimi auspiciis. CL. ex I. Institutionum libro selectas Theses Data liberrima cuilibet opponendi facultate Pestini mense Februario 1768 per triduum propugnaret [...] Martinus Járdoss, Nob. Hung. Osgyanensis ex Comitatu Kis Hontensi U. J. in primum Annum Auditor. [H. és ny. nélkül] [1768]

125 Lucae Pauli Perghold, Dissertatio Paraenetica ex qua Libertinismi, Indifferentismi, omnisque, quae multiplicata per orbem, malitiae, praecipua, quibus verbum Domini factum est in opprobrium, cerebrini aevi nostri Doctores, fabricatores mendacii \& cultores perversorum dogmatum Naturalistae dignoscentur esse causa, oblata [...] dum [...] conclusiones theologicas [...] publice propugnarent Bonus Merkhl Caelestinus Vallessich, Martinus <> in conv. Ord. Francisc. Budae, praeside Thaddeo a Thököly. Budae, Typ. Landerer, 17[68].

126 „[...] non alii, quam famosi ac tanto in pretio hoc nostro aevohabiti somniati Juris naturae Professores, qui ex eo reputantur, doctissimi, quod obsecuturi genio saeculi, cum peccatrice illa radice Antiocho Epihane secundum Gentium justitiam omnem cuique vivendi tribuant licentiam: oblivisci legem, \& immutare doceant omnes justificationes Dei [...] Profecto non aliis, quam famosis somniati, ut dixi, Juris naturae 
istentagadóknak tekint, de név szerint egyet sem nevez meg közülük. A megszokott metódussal bibliai példákon keresztül, egyházatyákra hivatkozva, túl sok - a jogtörténetkutatás számára megragadható - konkrétumot azonban nem említve lép fel az isteni törvény (lex Divina) védelmezőjeként.

7. Szintén egy jogi nyilvános vita téziseinek kinyomatását vette alkalmul Perghold, hogy egy először 1605-ben kiadott levélgyüjteményt is sajtó alá bocsásson a saját „,szerkesztésében”. Az utóbb Baronius nevet felvett, és a 16-17. század fordulóján élt neves konvertita katolikus teológus Justus Calvinus (Baronius) leveleinek hat könyvét - kiegészítve életrajzával - adta sajtó alá, összefüzve egy elsőéves joghallgató vegyes jellegü jogi téziseivel. ${ }^{127}$ Perghold mind az eredeti Epistola ad Lectorem-hez, mind a közölt levelekhez bőségesen füzött magyarázó történelmi, irodalmi és akár jogi megjegyzéseket, ${ }^{128}$ jelentősen kiegészítve az eredeti kiadás jegyzeteit.

Mint korábban is megállapítottuk, Perghold különböző munkáiban általában a természetjogi gondolatok elszánt ellenfeleként lépett fel és következetesen a konzervatív katolikus elvek híveként mutatkozott meg. Hogy ez mennyire találkozott a korabeli művelt olvasóközönség elvárásaival, nem tudhatjuk bizonyosan. Lehet, hogy a kereslet, de az is lehetséges, hogy az ügyes kiadói taktika járult hozzá ahhoz, hogy a 18. század második felében Perghold munkái gyakran fordultak elő a tudós jogokat tárgyaló jogi szakkönyvek között Pest és Buda polgárainak könyvtáraiban. ${ }^{129}$ Ez köszönhető lehetett művei viszonylagos népszerűségének, de annak is, hogy disputatiókhoz kötött munkái gyakran ajándékképpen is eljuthattak a közönséghez. ${ }^{130}$

hoc aevo nostro Professoribus Naturalistis. Hi enim sunt qui vaticinantur mendacia: hi, qui cordis sui prophetant seductiones [...]. "PERGHOLD, Dissertatio Paraenetica..., Praefatio.

127 Justi Baronir Veteracastrensis [...] Epistolarum Sacrarum et Amoebaearum libri VI. perennibus ... Antonii Károlyi de Nagy Károly honoribus. A Luca Paulo Perthold U.J.Doctore. [Belső címlapon:] Dum sub Gratiosissimis Ejusdemque ... Antonii Károlyi ... Auspiciis ex IV. imperialium institutionum libris selectas Hungarico-canonico-civiles et pro Parte Feudales Theses, Praeside [...] Luca Paulo Perthold Utriusque Jure Doctore Ejusdemque Sacrae Caesareae, \& Regio-Apostolicae Majestatis Authoritate in libera Regia Civitate Pesthiensi Professore Publico Ordinario Post Argumentum tertium data cuilibet liberrima opponendi facultate publice propugnavit [...] Petrus de Vaskó Nobilis Hungarus Vedrodiensis ex Comitatu Posoniensi U.J. in primum Annum Auditor Pesthini Die 26. Septembris anno 1768. Pestini, Typis Eizenbergerianis, [1768].

128 Saját jegyzeteiről így nyilatkozik az ajánlásban: „Sic varia has notas legentium mei erunt intuitu sensa. laudabunt, spero, \& plaudent, qui pie cordati: imprecabuntus mibi mali, timebunt tepidi, \& boni, qui adhuc non dum sat firmi sunt animi, nec inpenetrabili me protectum fidei sciunt scuto, soliciti erunt de me." Uo. Praefatio ad lectorem.

${ }^{129}$ Holl Béla, „Pest-Buda polgárainak könyvkultúrája a XVII-XVIII. században = Die Buchkultur der Bürger von Pest-Ofen im 17-18. Jahrhundert”, Tanulmányok Budapest múltjából 15 (Budapest: Akadémiai Kiadó, 1963), 310.

130 Szokás volt ugyanis, hogy egyes iskolai intézmények ünnepélyes vizsgákon vizsgatézisekkel együtt ajándékba könyveket osztottak. Így 1772-ben a pesti pálos studium generale Perghold Methodica címü művét terjesztette ily módon egy disputatio sollenne alkalmával. Vö. Pavercsıк, „Johann Gerhard Mauss...", 127. 
Paulus Lucas Perghold pesti jogtanár egy mára szinte teljesen elfeledett alakja a hazai jogi oktatás történetének és a tudománytörténetnek. A pesti jogi szakiskola rövid idejü létezése azonban egy olyan érdekes színfoltja a hazai oktatástörténetnek, amely újabb források előbukkanása esetén tovább erősítheti azon vélelmünket, hogy a hazai jogélet az eddig ismertnél erősebb szálakkal kapcsolódhatott a korabeli európai tendenciákhoz, illetve reflektálhatott azokra. 